\title{
SPECTRA AND CRITICAL POTENTIALS OF FIFTH GROUP ELEMENTS
}

\author{
By Arthur E. Ruark, F. L. Mohler, Paul D. Foote, and R. L. Chenault
}

ABSTRACT

Revised values of the critical potentials of $\mathrm{As}, \mathrm{Sb}$, and $\mathrm{Bi}$ are given. The resonance potentials of the neutral atoms correspond to the mean excitation voltages of groups of spectral lines. Photographs of the thermionic discharge in $\mathrm{Bi}$ were used to separate the excitation stages of the $\mathrm{Bi}$ atom; groups of spark lines appear at $\mathrm{I} 4 \pm \mathrm{I}$ and $25 \pm 5$ volts. The $\mathrm{Bi}$ absorption spectrum was studied. Classifications of lines of $\mathrm{N}^{+}, \mathrm{As}$, $\mathrm{Sb}, \mathrm{Bi}$, and $\mathrm{Bi}^{+}$were obtained. $\mathrm{As}, \mathrm{Sb}$, and $\mathrm{Bi}$ have doublet spectra. To describe phenomena connected with the existence of very narrow doublet levels in $\mathrm{Al}^{+}, \mathrm{Bi}$, and other elements it is proposed to introduce a new quantum number called the fine quantum number.

\section{CONTENTS}

I. Introduction

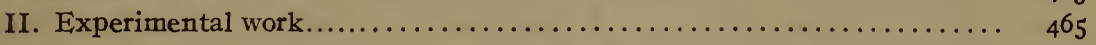

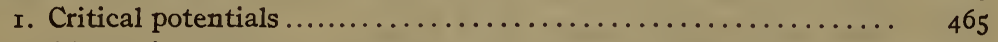

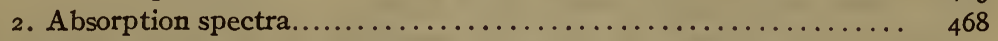

3. Spectroscopic study of stages in the thermionic discharge....... 469

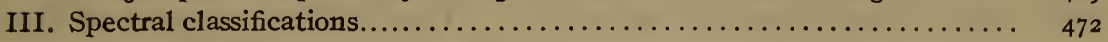

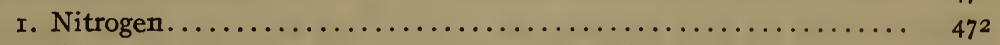

2. General characteristics of the spectra of $\mathrm{As}, \mathrm{Sb}$, and $\mathrm{Bi} \ldots \ldots \ldots \quad 47^{2}$

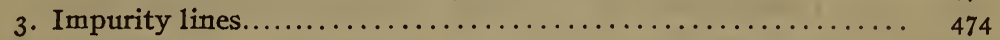

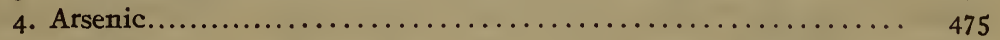

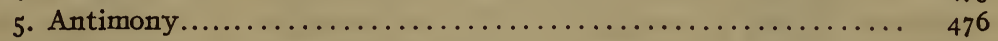

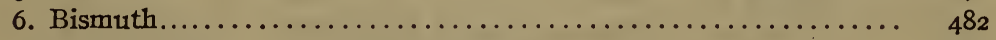

7. Higher stages in the bismuth spectra................... 485

\section{INTRODUCTION}

This paper discusses the arc spectra and critical potentials of arsenic, antimony, and bismuth, and includes some information on the spectrum of singly ionized nitrogen and the various spark spectra of bismuth. The data are voluminous, so we shall first outline the principal facts regarding these spectra. The elements nitrogen, phosphorus, arsenic, antimony, and bismuth lie on the right side of the fifth column of the periodic table. Their spectra are poor in lines compared with those of most elements on the right side of the periodic table. Stark and Hardtke ${ }^{1}$ gave measures of a spectrum which they ascribe to the neutral

1 Ann. der Physik., 56, p. 363; 1918. 
atom of nitrogen, but the range of wave lengths is too narrow to justify an extended study of these lines. The great difficulty in obtaining the spectrum of neutral nitrogen is that the most common type of electron impact gives a molecule ion and an electron. ${ }^{2}$ With low-current densities line spectra become visible only at about 70 volts. $^{3}$ Probably a similar difficulty exists in the case of phosphorus. The line spectra of phosphorus have been studied by only a few observers, and the arc lines have not been well separated from the spark lines. Further observations will be required before this spectrum can be analyzed with economy of effort.

The conditions are quite different in the case of arsenic, antimony, and bismuth. As we pass to higher atomic weights in this column, dissociation can be obtained with weaker stimuli, sa that the arc spectra of these three elements contain many reversed lines. Further, the lines due to the neutral atoms can be distinguished from the others with comparative ease. Thirty years ago Kayser and Runge ${ }^{4}$ discovered the most important constant differences in the arc spectra of these elements. Series of a conventional type were not found and no further classifications have been attempted since that time.

Our classification of the arc spectra of these elements shows that they possess doublet structure. The doublet spectra of the alkalies and of the aluminum group are known to be associated with the transitions of a single valence electron more loosely bound than any other electron in the atom. However, chemical evidence is not favorable to the assumption of a similar state of affairs in arsenic, antimony, and bismuth. Valences vary from 2 to 5 , but are predominantly 3 and 5 . It is the concensus of opinion that these three metals do not exhibit the valence one in any of their compounds. This strongly suggests that the arc spectrum arises from transitions of one electron of a group of three having azimuthal quantum numbers greater than unity.

We have studied the absorption spectra of arsenic, antimony, and bismuth, obtaining a line absorption spectrum only in the case of bismuth, and have also photographed the thermionic discharge in the latter element at potentials ranging between 4 and 60 volts. The spark lines of bismuth have been separated into at least three classes, the first of which appears at about 14 volts.

2 Smyth, Nature, 111, p. 810; 1923.

${ }^{3}$ Duffendack, Phys. Rev., 20, p. 665; 1922.

4 Ann. der Physik., 52, p. 93; r894. 
We have been able to classify nearly one-half the lines which can by any possibility belong to the neutral atoms of $\mathrm{As}, \mathrm{Sb}$, and $\mathrm{Bi}$, and have found a fragmentary system of energy levels which accounts for some of the strongest lines in the 14 -volt spectrum of $\mathrm{Bi}$.

In $\mathrm{As}$ and $\mathrm{Bi}$ the critical potentials seem to be related to the atomic spectra in a simple manner, and have been used to obtain rough values for the spectroscopic terms. The question whether this procedure is justifiable in the case of $\mathrm{Sb}$ will be treated in the sequel.

We shall discuss, also, a multiplet found among the lines of $\mathrm{N}^{+}$.

\section{EXPERIMENTAL WORK}

\section{CRITICAL POTENTIALS}

Foote, Rognley, and Mohler determined the critical potentials of $\mathrm{As}, \mathrm{Sb}$, and $\mathrm{Bi}$ in I918, but data were published only for As. The results for $\mathrm{Sb}$ and $\mathrm{Bi}$ were given in "The Origin of Spectra," without any experimental details and with cautions that they were not to be relied on. We have reexamined the curves for antimony and bismuth, and give slightly revised results for the whole family in Table $\mathrm{I}$. The values for antimony must still be considered as provisional.

TABLE 1.-Critical Potentials of the Nitrogen Group

\begin{tabular}{|c|c|c|}
\hline Element & $\begin{array}{l}\text { Inelastic } \\
\text { collision } \\
\text { potentials }\end{array}$ & Ionization \\
\hline $\begin{array}{l}\mathrm{N} \\
\mathrm{P} \\
\mathrm{P}\end{array}$ & $\begin{array}{l}8.18 \pm 0.1 \\
5.80 \pm 0.1 \\
4.69 \pm 0.1 \\
1.7 \pm 0.5 \\
5.7 \pm 0.5 \\
1.9 \pm 0.1\end{array}$ & $\begin{array}{r}16.9 \pm 0.5 \\
13.3 \pm 0.5 \\
11.54 \pm 0.5 \\
8.5 \pm 1.0 \\
8.0 \pm 0.5\end{array}$ \\
\hline
\end{tabular}

1 Inelastic collisions occur at I.9, 3.9, and 5.7 volts. (See page 467. )

For these elements, the ionization potentials were observed by the method of total-current measurement and inelastic impacts were detected by the partial-current method in simple threeelectrode tubes. In order to interpret the data for arsenic and antimony it is of importance to settle definitely the nature of the critical potentials for bismuth, these having been investigated in considerable detail. Temperatures between 700 and $800^{\circ} \mathrm{C}$. were used for $\mathrm{Bi}$. The measurements proved very difficult and

${ }^{6}$ Phys. Rev., 13, p. 59; 9919. 
gave rather discordant results. However, several of the better curves showed consistent values for the critical potentials which may be interpreted on the basis of the energy diagram (fig. I).

Aside from the numerical agreements which are obtained, there is good evidence that these potentials are characteristic of the atom. The relative intensity of bands and lines in the absorption spectrum shows the presence of a large percentage of atoms at the temperatures of the low voltage arc experiments, as might be expected from the data on vapor pressure. The percentage would be increased by the dissociation due to the electron current.

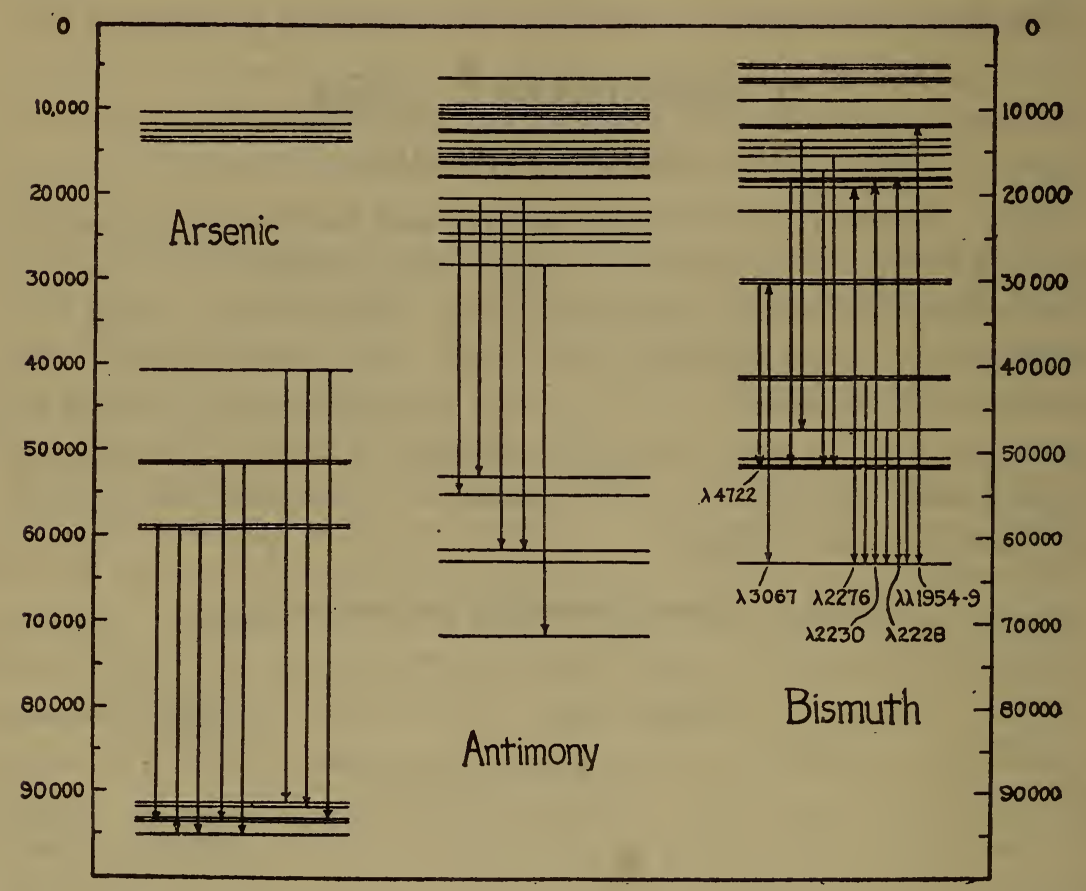

FIG. I.-Energy levels and prominent spectrum lines of arsenic, antimony, and bismuth

The extent of this increase is remarkable, for the low-voltage spectra are practically free of band structures. Those which do occur (in exposures taken at the beginning of the run) are not the bands appearing in the absorption spectrum, but are due to impurities.

Partial current measurements show prominently two drops in the current-voltage curves at an interval of 2.0 volts. Some curves show other drops, notably one at a potential I.8 volts above the second resonance drop. From Figure I we see that atomic bismuth will have a large number of inelastic impact 
potentials which will not be completely resolved by electrical methods. The three lowest, at I.4, I.9, and 2.6 volts, give rise only to weak spectral lines corresponding to zero change of the azimuthal quantum number, and are analogous to the metastable state potentials of the aluminum group. The mean value, I. 9 volts, corresponds well with the observed interval between the first two inelastic collisions. The raies ultimes 3067 and $4722 \mathrm{~A}$ will be excited at 4.04 volts, so that the effect of this energy loss will be superposed on that of the second I.9-volt loss. Thus we may use the first drop to determine the initial potential correction; it is found that the three impacts mentioned lie at r.9, 3.9, and 5.7 volts. Possibly the drop at 5.7 is caused in part by combinations of the 1.9 and 4.0 volt losses, but it must be noted that many strong spectral lines, including the absorption lines 2276 , 2230, 2228, I959, and $1954 \mathrm{~A}$, will be excited at a mean potential of 5.8 volts. The ionization potential is $8.0 \pm 0.5$ volts, and this is in close agreement with the observed range of spectral terms. This measurement should be repeated, as the probable error is large, and the method used is probably not the best one for this element. We conclude that all these potentials are characteristic of the atom and that the lowest group of excitation potentials (mean value $r .9$ volts) are the most prominent feature in the inelastic impact curves, although they give rise only to weak spectrum lines. In this respect the behavior of bismuth is quite similar to that of thallium. ${ }^{6}$

For arsenic and antimony also, there is little difficulty about obtaining a line spectrum free of bands, although the unexcited vapors at the temperatures used consist almost entirely of $\mathrm{As}_{4}$ and $\mathrm{Sb}_{4}$. In arsenic at 400 to $500^{\circ} \mathrm{C}$. it may be supposed that a considerable percentage of the atoms are in the states called ${ }_{3} D_{1}, 3 D_{2}$, and $3 d_{1}$ (see fig. $\mathrm{r}$ ). The five lowest energy levels are so close together that the various inelastic collisions giving rise to transitions upward from these levels will not be separated in the electrical measurements. The observed potential is probably the superposed effect of the excitation voltages for a dozen or more spectrum lines between 3 II 9 and 2349 A. As a matter of fact, the mean voltage required to produce the seven raies ultimes (see Table 3 ) is 4.80 , while the observed potential of inelastic impact is 4.7 .

The experimental results for antimony are less reliable than those for bismuth and arsenic. No satisfactory correlation of

6 Mohler and Ruark, J. O. S. A. and R. S. I., 7, p. 819; 1923. 
the critical potentials and the excitation stages of the arc spectrum has been attained, although the mean wave number of the raies ultimes agrees closely with the interval between the two observed potentials of inelastic collision. The energy diagram suggests the existence of other critical potentials much lower than this, in analogy to the 1.9 -volt potential. in $\mathrm{Bi}$; however, it seems impossible to make a definite statement on the basis of existing data.

\section{ABSORPTION SPECTRA}

The absorption spectra of $\mathrm{As}, \mathrm{Sb}$, and $\mathrm{Bi}$ were photographed, utilizing the continuous background furnished by a spark under water, which passed between tungsten electrodes about $2.5 \mathrm{~mm}$ in diameter and $\mathrm{I} \mathrm{cm}$ apart. A $\mathrm{I}-\mathrm{kw}$. 20,000-volt radio transformer was connected to an oscillatory circuit containing a quenched spark gap, a glass plate condenser (immersed in oil) of about 0.005 microfarad, and the primary of a Tesla coil. This coil was made in accordance with a design described by Gibson and others $;^{7}$ the secondary was connected direct to the terminals of the spark. A steady flow of distilled water was essential when exposures of more than a minute or two were required. If properly tuned this apparatus gives a background which does not contain any superposed emission or absorption lines. The limit of the spectrum is determined by the absorption bands of oxygen ${ }^{8}$ and by scattering due to the air and to the fused quartz plates in the path of the light. To record the lines I 954 and 1959 $\mathrm{A}$ of $\mathrm{Bi}$ an exposure of about 40 minutes, with the smallest size of Hilger quartz spectrograph, was required. For all other work a size E Hilger instrument was used, with exposures ranging between 2 and 40 minutes, depending on the spectral region to be examined. Satisfactory line absorption spectra of $\mathrm{Bi}$ were obtained at temperatures between 800 and $\mathrm{I}, 050^{\circ} \mathrm{C}$. After this work was completed a paper by Grotrian ${ }^{9}$ appeared, dealing with the absorption spectra of several metals. He states that bsimuth has an absorption line at $3067 \mathrm{~A}$ and a group of bands in the region 2600 to $2900 \mathrm{~A}$, as well as a group in the visible region at higher temperatures. We have obtained absorption lines at $3067,2276,2230,2228$, 1959, and $1954 \mathrm{~A} . \quad 2276 \mathrm{~A}$ is much stronger than $2230-2228 \mathrm{~A}$ in absorption. Correspondingly it is usually observed to be weaker than 2230-2228 A in emission, for it is reduced relatively more in intensity by the cooler vapors at the

7 B. S. Sci. Papers, 18, p. 128; 1922.

8 The first prominent oxygen band is at 1919.2 A. Fainter ones occur at 1940 and 1957 A. See $I_{1 .}$ and E. Bloch, C. R., 158, p. I16r; I914.

${ }^{9}$ Zeits. für Phys., 18, 169; 1923. 
boundary of the luminous region. All the lines listed arise in transitions to the lowest level of the atom and are shown in the energy diagram of $\mathrm{Bi}$ (fig. $\mathrm{I}$ ). At $\mathrm{I}, 050^{\circ} \mathrm{C}$. there was not the slightest trace of spectrum lines arising on other low-lying orbits; indeed, the Boltzmann distribution law shows that they should not be expected.

At $800^{\circ} \mathrm{C}$. scarcely a trace of bands could be observed, but at the higher temperatures and, accordingly, higher pressures, they were fully as prominent as the lines. A band group having about I 7 heads lies between 2874 and $2672 \mathrm{~A}$. These bands are degraded toward the red. The frequency separation of corresponding points in neighboring bands is constant within the limits of our rough measurements, and amounts to about $175 \mathrm{~cm}^{-1}$. Many of the bands have a narrow region of decreased absorption near their heads. A second group characterized by the same frequency separation begins at $2205 \mathrm{~A}$ and extends toward shorter wave lengths. For this reason low temperatures (low pressures) had to be used in obtaining the lines 1959 and $1954 \mathrm{~A}$. Attempts were made to photograph line absorption spectra of arsenic and antimony. Both elements have a continuous absorption in the ultra-violet, which spreads toward longer wave lengths as the vapor pressure rises. The results of our experiments are in accord with the descriptions and photographs published by Dobbie and Fox. ${ }^{10}$

\section{SPECTROSCOPIC STUDY OF STAGES IN THE THERMIONIC DISCHARGE}

Bismuth was boiled in a silica tube sealed at the bottom and closed at the top with a water-cooled metal plate. A tube carrying the electrodes and the observing tube passed through holes in tire metal top.

The tungsten cathode was surrounded by a cylindrical sheet steel anode about $\mathrm{I} \mathrm{cm}$ in diameter and the inside of the quartz tube was lined with sheet steel which was kept at the same potential as the anode. The lower end of the tube was heated by an electric furnace to temperatures between 800 and $900^{\circ} \mathrm{C}$. Outside the furnace and tube was mounted a coil of copper wire. A large current in this coil maintained a magnetic field, which concentrated the discharge in a beam, nearly parallel to the line of sight.

Thermionic currents up to I ampere could be maintained above the ionization potential, but at lower voltages ro milliamperes was about the maximum current. Light reflected diffusely from the incandescent cathode was troublesome and set a limit (about two

${ }^{10}$ Froc. Roy. Soc. A., 98, p. 147; 1920.

$95366^{\circ}-24-2$ 
hours) to the length of exposure that was useful in photographing the low-voltage stages. For this reason the work with pure bismuth was supplemented with a few photographs of discharges in a mixture of sodium and bismuth. Large currents could then be maintained at potentials slightly above the ionization potential of sodium, 5.I volts. This made it possible to determine excitation stages for faint lines and lines in the far ultra-violet.

In estimating the true potential in pure bismuth it was assumed that the potential at the arc point was 8 volts. This gave a correction to the applied potential ranging between +0.5 and +0.8 , but the values obtained by this method are subject to errors of possibly I volt.

In discharges above the arcing potential mean-current densities of the order of $0 . \mathrm{I}$ to I amperes per $\mathrm{cm}^{2}$ were used.

The spectral region studied extends from 4722 to $2157 \mathrm{~A}$. Exposures were obtained from 4 to 60 volts; those taken below 8 volts confirm the classification of the lines of neutrai $\mathrm{Bi}$. As nearly as could be judged, the more prominent lines appeared in every case at voltages agreeing with those predicted from the classification. A 5-volt exposure showing only the resonance lines 3067 and $4722 \mathrm{~A}$ is reproduced in Figure 2. The 8-volt exposure is characteristic of the arc spectrum, while the I6-volt photograph shows the first set of lines to appear after the arc spectrum. At 60 volts nearly all the spark lines recorded by more than one observer are present.

The photographs taken above the ionization potential include the following voltages: Io, I4, I5, I6, 20, 25, 30, 35, 40, 45, 50, and 6o. Table 2 gives a list of the spark lines observed. Opposite each line is tabulated the voltage at which it first appears upon our plates, with remarks in some cases as to the manner of enhancement with increasing voltage.

Schuster and Hemsalech ${ }^{11}$ have studied the velocities with which the luminous vapors in the bismuth spark pass outward from the poles, while Hemsalech ${ }^{12}$ has described the effects of self-induction on prominent $\mathrm{Bi}$ lines. Their results afford support to the assignment of the excitation stages for the more prominent lines in Table 2, and enable us to state, in addition, that 5209 and $527 \mathrm{x} \mathrm{A}$ belong to a higher stage than the I4-volt lines. In attempting to obtain from Table 2 the approximate critical potentials of the spark spectra, the question arises whether excitation by electron collisions with ions was probable. High-current 


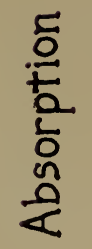

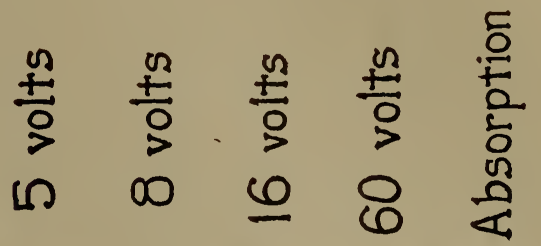

$\stackrel{v}{*}$
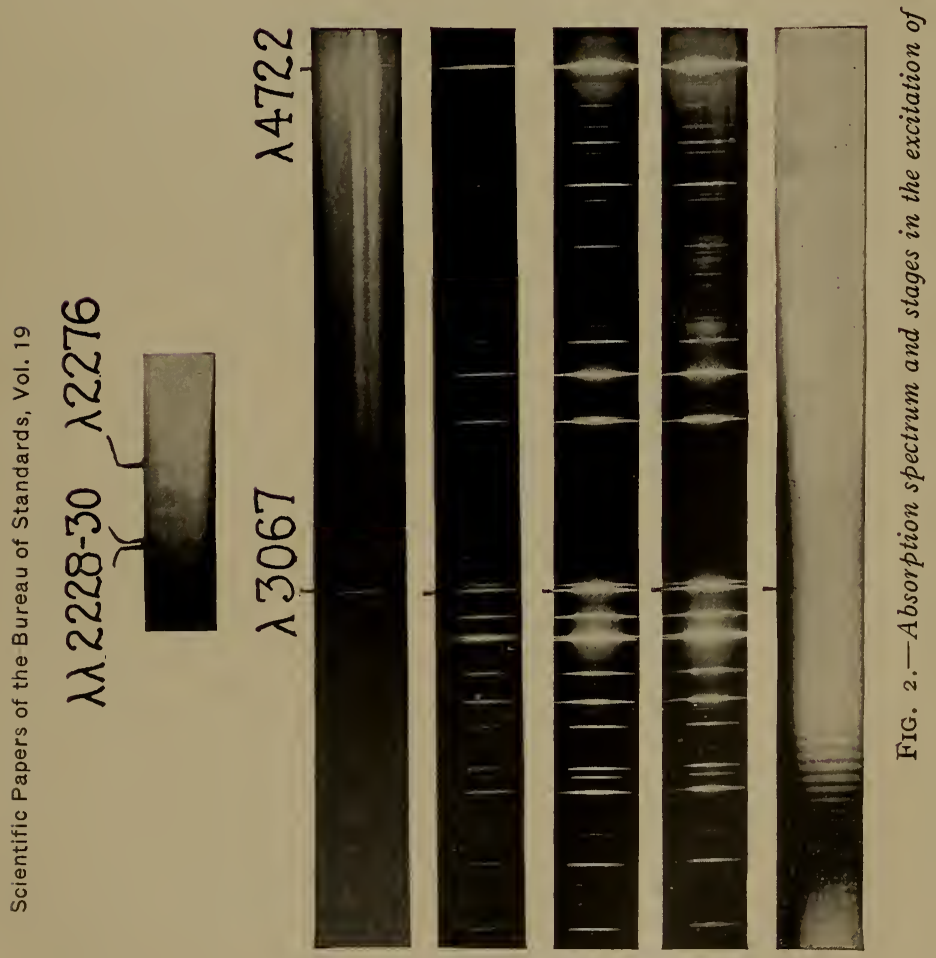
densities favor this type of excitation, and by studying the discharge with different current densities at each potential used, it should be possible to determine the origins of many spectral lines and of the critical potentials encountered. Such a study was not made for $\mathrm{Bi}$, but comparison with results obtained with other elements indicates that collisions of electrons with ions will be an appreciable factor at the current densities used.

The first stage in the spark spectrum appears at $\mathrm{I} 4 \pm \mathrm{I}$ volts. Other stages occur at $25 \pm 5$ and probably at $45 \pm 5$ volts. Intermediate stages may occur, as the excitation potentials of the many fainter lines are very uncertain.

Spectroscopic stages in arsenic and antimony have not been studied in detail, although photographs of the antimony spectrum have been obtained at several potentials up to 30 volts.

TABLE 2.-Appearance Voltages of Bi Lines

\begin{tabular}{|c|c|c|c|}
\hline$\lambda \mathrm{I} . \mathrm{A}$. & Intensity & $\begin{array}{c}\text { Voltage } \\
\text { of ap- } \\
\text { pearance }\end{array}$ & Remarks and classification \\
\hline $\begin{array}{l}2,297.5 \ldots \ldots \\
2,345.9 \ldots \ldots \\
2,368.40 \ldots \ldots \\
2,414.80 \ldots \ldots \\
2,499.51 \ldots \ldots\end{array}$ & 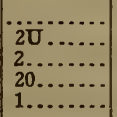 & $\begin{array}{l}60 \\
50 \\
16 \\
20 \\
25\end{array}$ & On one plate only. May be $\mathrm{Hg}$. \\
\hline $\begin{array}{l}2,500.5 \ldots \ldots . \\
2,544.4 \ldots \ldots . \\
2,594.05 \ldots \ldots . \\
2,679.9 \ldots \ldots . \\
2,692.9 \ldots \ldots .\end{array}$ & 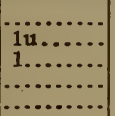 & $\begin{array}{l}35 \\
14 \\
8.5 \\
30 \\
15\end{array}$ & Much enhanced at higher voltages. \\
\hline $\begin{array}{l}2,713.4 \ldots \ldots . \\
2,746.35 \ldots \ldots \\
2,803.48 \ldots \ldots \\
2,803.69 \ldots \ldots \\
2,805.2 \ldots \ldots\end{array}$ & $\begin{array}{l}2 u \\
1 \ldots \\
4 \ldots \\
5 \ldots\end{array}$ & $\begin{array}{l}16 \\
25 \\
14 \\
14 \\
14\end{array}$ & $\begin{array}{l}\text { Do. } \\
\text { Not separated. Enhanced at higher voltages. } \\
\text { Enhanced at higher voltages. }\end{array}$ \\
\hline $\begin{array}{l}2,847.6 \ldots \ldots . \\
2,855.68 \ldots \ldots \\
3,111.4 \ldots \ldots . \\
3,115.4 \ldots \ldots \\
3,187.6 \ldots \ldots\end{array}$ & 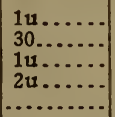 & $\begin{array}{l}50 \\
30 \\
50 \\
14 \\
15\end{array}$ & Visible at 15 , but strongly eihanced at higher voltages. \\
\hline $\begin{array}{l}3,296.0 \ldots \ldots \\
3,299.7 \ldots \ldots . \\
3,315.2 \ldots \ldots \\
3,393.1 \ldots \ldots \\
3,394.1 \ldots \ldots\end{array}$ & 1u............. & $\begin{array}{l}14 \\
14 \\
14 \\
14 \\
14\end{array}$ & $\begin{array}{l}G-N \\
\text { Not separated on our plates. }\end{array}$ \\
\hline $\begin{array}{l}3,431.01 \ldots \ldots \\
3,451.05 \ldots \ldots \\
3,455.2 \ldots \ldots \\
3,473.9 \ldots \ldots \\
3,485.6 \ldots \ldots\end{array}$ & 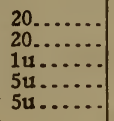 & $\begin{array}{l}14 \\
45 \\
14 \\
40 \\
14\end{array}$ & $\begin{array}{l}G-L . \\
G-K . \text { Wave length adjusted. }\end{array}$ \\
\hline $\begin{array}{l}3,541.4 \ldots \ldots . \\
3,613.8 \ldots \ldots . \\
3,654.4 \ldots \ldots \\
3,695.55 \ldots \ldots \\
3,756.4 \ldots \ldots\end{array}$ & $\begin{array}{l}2 u \ldots \\
5 \mathrm{r} \ldots \ldots \\
1 \mathrm{u} \ldots \\
50 \ldots \ldots \\
2 \mathrm{w} \ldots\end{array}$ & $\begin{array}{l}35 \\
25 \\
14 \\
25 \\
14\end{array}$ & $\begin{array}{l}\text { Weak at } 35 \text { volts. } \\
H-N \text {. } \\
\text { Weak at } 25 \text { volts. }\end{array}$ \\
\hline $\begin{array}{l}3,792.8 \ldots \ldots . \\
3,811.2 \ldots \ldots . \\
3,816.1 \ldots \ldots . \\
3,846.0 \ldots \ldots \\
3,864.2 \ldots \ldots\end{array}$ & $\begin{array}{l}50 \mathrm{u} \ldots \ldots \\
2 \mathrm{u} \ldots \ldots \\
2 \mathrm{u} \ldots \\
10 \mathrm{u} \ldots\end{array}$ & $\begin{array}{l}14 \\
14 \\
14 \\
25 \\
14\end{array}$ & $\begin{array}{l}H-L . \\
H-K .\end{array}$ \\
\hline $\begin{array}{l}4,079.25 \ldots \ldots \\
4,259.70 \ldots \ldots \\
4,302.10 \ldots \ldots \\
4,340.6 \ldots \ldots\end{array}$ & $\begin{array}{l}30 \ldots \ldots \\
100 \ldots \ldots \\
50 \ldots \ldots \\
21 . \ldots \ldots\end{array}$ & $\begin{array}{l}14 \\
14 \\
14 \\
14\end{array}$ & Probably due to lead. \\
\hline $\begin{array}{l}4,386.8 \ldots \ldots \\
4,391.4 \ldots \ldots \\
4,477.1 \ldots \ldots \\
4,561.15 \ldots \ldots\end{array}$ & $\left|\begin{array}{l}2 \mathrm{u} \ldots \ldots \\
1 \mathrm{u} \ldots \ldots . \\
1 \mathrm{u} \ldots \ldots \\
20 \mathrm{R} . \ldots\end{array}\right|$ & $\begin{array}{l}8.5 \\
16 \\
25 \\
45\end{array}$ & $\begin{array}{l}\text { Not recorded in the arc in air. } \\
\text { Faint at all voltages. }\end{array}$ \\
\hline
\end{tabular}




\section{SPECTRAL CLASSIFICATIONS ${ }^{13}$}

\section{NITROGEN}

Professor Fowler ${ }^{14}$ has pointed out seven lines almost certainly due to doubly ionized nitrogen, which exhibit the doublet regularities characteristic of the neutral atoms of third group elements. We have found a six-line multiplet of the type $m p-n p$, which obeys the intensity rules fairly well. These lines are probably due to singly-ionized nitrogen, for they appear at a lower excitation than Fowler's doublets. This striking group is shown in Plate XIII of Fowler's article. The data are as follows:

\begin{tabular}{|c|c|c|c|}
\hline$\lambda$ I. A. & $\begin{array}{l}\text { Inten- } \\
\text { sity }\end{array}$ & $\nu$ & $\begin{array}{c}\text { Classifica- } \\
\text { tion }\end{array}$ \\
\hline $\begin{array}{l}4,643.10 \\
4,630.55 \ldots \ldots \ldots \\
4,621.40 \ldots \ldots \ldots \ldots \\
4,613.88 \ldots \ldots \ldots \ldots \\
4,607.16 \ldots \ldots \ldots \ldots \\
4,601.48 \ldots \ldots \ldots \ldots\end{array}$ & $\begin{array}{r}7 \\
10 \\
7 \\
6 \\
7 \\
8\end{array}$ & $\begin{array}{l}21,531.29 \\
21,589.67 \\
21,632.40 \\
21,667.65 \\
21,699.24 \\
21,726.02\end{array}$ & $\begin{array}{l}m p_{1}-n p_{2} \\
m p_{1}-n p_{1} \\
m p_{2}-n p_{3} \\
m p_{2}-n p_{2} \\
m p_{3}-n p_{2} \\
m p_{2}-n p_{1}\end{array}$ \\
\hline
\end{tabular}

Attention may also be drawn to the frequency difference, 51.69, occurring among the lines of singly-ionized nitrogen:

$\begin{array}{lll}4,236.99 & 4 \text { h } & 23,595 . \text { or } \\ 4,227.74 & 2 \text { h } & 23,646.62 \\ 4,043.44 & 2 \text { h } & 24,723.84 \\ 4,035.09 & 4 \text { h } & 24,775.59\end{array}$

\section{GENERAL CHARACTERISTICS OF THE SPECTRA OF As, Sb, AND Bi}

The arc spectrum of arsenic is very poor in lines. There are no lines in the visible region, for two reasons: (I) There is a gap of $32,000 \mathrm{~cm}^{-1}$ in the energy diagram, lying just above the five lowest orbits, and (2) the terms lying above the gap do not combine in such a way as to yield lines in this region, although many such combinations are numerically possible. A similar phenome-

\footnotetext{
13 The following abbreviations are used to indicate the character of spectrum lines: $\mathrm{R}=$ reversed.

$\mathrm{u}$ or $\mathrm{h}=$ hazy, diffuse.

$\mathrm{U}$ or $\mathrm{H}=$ very diffuse.

$\mathrm{b}=$ broad.

$\mathrm{B}=$ very broad.

$\mathrm{r}=$ diffuse toward red.

$\mathrm{v}=$ diffuse toward violet.
}

In this paper all wave lengths recorded originally on the Rowland scale have been reduced to I. A., with the exception of the infra-red measures of Randall. For these the errors estimated by Randall are larger than the corrections, and the latter are not known with any certainty beyond $8800 \mathrm{~A}$. The wave numbers given are in every case the reciprocals of the wave lengths in vacuo obtained from the wave lengths listed in the tables. The corrections to vacuum were made in accordance with the data of Meggers and Peters, B. S. Bull. 14, p. 697; Igr8. The series notation is that of Paschen.

${ }^{14}$ Monthly Notices, R. A. S., 80, 692; I920. 
non is found in $\mathrm{Sb}$ and $\mathrm{Bi}$. The gap in the spectrum becomes narrower and shifts toward longer wave lengths as we pass to higher atomic numbers. In each case the vacant region in the energy diagram is just above a comparatively compact group of low-lying orbits (see fig. I). In As and $\mathrm{Sb}$ this group consists of five orbits. From the nature of the combinations we have designated these orbits in arsenic as $3 D_{1}, 3 D_{2}, \mathrm{I} s, 3 d_{1}$, and $3 d_{2}$. The capital letters are used only to avoid some distinguishing mark, such as a prime, because it seems reasonable to assign the same term number to both ${ }_{3} D$ and $3 d$ orbits. In all probability these pairs of orbits are characterized by the same total, azimuthal and inner quantum numbers, the difference of energy being attributable to screening. It will be understood that the orbits ${ }_{4} d_{1,2}$ might just as well be designated as $4 D_{1,2}$.

In $\mathrm{Bi}$ the separations of the levels corresponding to the $3 d$ and ${ }_{3} D$ doublets in As are, of course, very large, and a new feature appears. In place of the energy level ${ }_{3} D_{1}$ of As we have a pair of energy levels separated by $1.85 \mathrm{~cm}^{-1}$, and in place of the energy level $3 d_{1}$ we have a pair separated by $14.05 \mathrm{~cm}^{-1}$. (Compare, however, the alternative classifications mentioned on page 483.)

By analogy with arsenic, the first pair is designated as $3 D_{1}{ }^{A}$ and $3 D_{1}{ }^{B}$, the second, as $3 d_{1}{ }^{A}$ and $3 d_{1}{ }^{B}$, while the remaining levels of the group of seven are assigned the same names as the arsenic levels which occupy corresponding positions. The group of five in $\mathrm{Sb}$ is given the same notation as in arsenic, but these assignments may have no physical significance. The combinations in the $\mathrm{Sb}$ and $\mathrm{Bi}$ spectra are such that we are not justified in specifying the character of their energy levels at the present stage of our knowledge.

The $1.85 \mathrm{~cm}^{-1}$ separation in $\mathrm{Bi}$ gives rise to extremely narrow doublets in the visible and ultra-violet regions of the spectra, and it is not to be expected that the corresponding doublets in As and $\mathrm{Sb}$ could be resolved except by a very laborious and elaborate study. However, the analogues of the $14 \mathrm{~cm}^{-1}$ separation should be observed with reasonable ease, and it would be of considerable interest to determine whether they actually exist. A somewhat similar term multiplicity was observed by Paschen ${ }^{15}$ in the spectrum of $\mathrm{Al}^{+}$, which consists of singlet and triplet series. Paschen found that the terms $4 f_{1}, 4 f_{2}, 4 f_{3}$, and $4 F$ are each very narrow doublets. From a study of fine structures observed in the spectra of $\mathrm{Cu}, \mathrm{Hg}, \mathrm{Al}^{+}, \mathrm{Tl}$, and $\mathrm{Bi}$, we conclude that such mul-

${ }^{15}$ Ann. d. Physik., 71, p. 537; 1923. 
tiplicities require the introduction of a new quantum number, for which we propose the name "fine quantum number" and the designation $f$. It is reasonable to suppose that small quantized differences in the energy of the interior electron shells (or perhaps different orientations of an asymmetric nucleus) correspond to the various values of the fine quantum number. While there may be fine structures in the line spectra of isotopic atoms which are brought about by the variations in the mass or form of the nucleus, we have good evidence, based on the combinations observed in the elements mentioned above, that there are other types of fine structure which arise entirely from variations in the energy levels of a single atom. The facts may be illustrated by a simple case. If we observe the spectrum of an element of given atomic number, which is composed of two isotopes, we should expect that each energy level would appear to be split into two levels, which we may designate as "low" and "high." Combinations between "low" levels and "high" levels could not occur, while cases are known in which three or four fine structure components arise from two energy levels, each consisting of a narrow doublet. It was through the study of the fine structures observed in Bi that we were led to classify these spectra.

The magnitudes of the highest terms in these spectra were estimated from the resonance and ionization potentials. It is believed the assignments in $\mathrm{As}$ and $\mathrm{Bi}$ are not in error by more than $4,000 \mathrm{~cm}^{-1}$. The critical potentials of $\mathrm{Sb}$ have not been correlated with the spectrum in a satisfactory manner, and the uncertainty of the term magnitude is still very great.

The constant differences discovered by Kayser and Runge were a great aid in finding further regularities. They pointed out the relationships of 20 lines in $\mathrm{As}, 34$ in $\mathrm{Sb}$, and 25 in $\mathrm{Bi}$. All of the differences noted were genuine with the exception of two in $\mathrm{Sb}$. This changes the classification of 2395, 2212, 2352, and 2175 A.

\section{IMPURITY LINES}

No extensive attempt was made to locate impurity lines in the lists of spark wave lengths in Kayser's Handbuch, but the following were noted:

In the Arsenic Lists.

Bi: $4722.62,4259.61,3067.82$.

$\mathrm{Pb}: 4057.94,3740.12,3683.56,3671.90,3639.74,3572.94,2833.2,2802.1,2663.22$, 2614.09.

$\mathrm{Sb}: 4352.28$ ?, 3267.60, $3232.67,2598.10,2528.49,2445.6 \mathrm{r}, 2306.7$ ?. 
Al: $3961.63,3944.16$.

As: $5651.39,555^{8.06}, 5497.73,455^{2.29}, 4543.64,4539.84,4494.48,4474.44,4466.48$, $4458.6 \mathrm{r}, 4368.50,4336.77,4249.6 \mathrm{r}$ ?, 4082.60, 4006.2 I, 3948.69, 2349.84, $2288.2 \mathrm{r}$.

Bi: 3024.85 ?.

Cu: $5782.15,5646.3,5599.76,5463.7,5218.14,3273.97,3247.55$.

$\mathrm{Pb}: 5609.2,5372.9,4387.01,4245.34,4058.00,3739.95,3683.47,3639.57,2663.3 \mathrm{I}$, $26 \mathrm{I}_{4} .33,2246.99,2203.65,2170.23$.

Si: $2528.58,2519.3$ r, $2218.15,2216.5^{2}$ ?.

Sn: $2706.73,257$ 1.64, 2429.55 .

Walters has pointed out that several of the lines given by Kretzer between 7 I45 and 7480 A are second order lines due to $\mathrm{Pb}$ and $\mathrm{Sb}$. Two lines were outstanding with wave lengths $7343.4 \mathrm{I}$ and $7 \mathrm{r} 8 \mathrm{I} .09 \mathrm{~A}$. The first is $\mathrm{Pb} 367 \mathrm{I} \mathrm{A}$, and there can be little doubt that the sole survivor is also spurious. Kretzer's line at 6495.I 7 may be the second order of $\mathrm{Cu} 3247.66 \mathrm{~A}$.

In the Bismuth Lists

Ag: 338r.9, 3279.9, 2437.2 .

Cd: $2265.11,2144.58$ ?

$\mathrm{Hg}: 2847.7$ ?, 2224.73 ?.

$\mathrm{Pb}: 4387.0$ ?, 3740.10, 3683.64, 3639.75, 3572.92, 26r3.74, 2446.3, $2402.08,2394.0$.

The following lines listed by Kayser and Runge as occurring in the arc did not appear on our plates: $2944.38,2892.98,2582.17$, $2532.65,2489.5,2360.0,2309.4,2281.39,2224.27$, and 2203.2 A.

\section{ARSENIC}

The Zeeman effect of arsenic has not been studied, and no measures have been made from 8823 to $6404 \mathrm{~A}$. Randall ${ }^{16}$ gives wave lengths from 10614 to $8823 \mathrm{~A}$. We do not give the list, since no classifications of any certainty were obtained. The characteristic arc spectrum extends from 3 II 9 A toward shorter wave lengths. Kayser's and Runge's measurements were used to $2144 \mathrm{~A}$, inclusive, and those of $\mathrm{L}$. and $\mathrm{E}$. Bloch ${ }^{17}$ beyond that point. The wave lengths are recorded only to I83I A, since we could not classify any shorter radiations. Tables 3 and 4 give the classifications and term magnitudes, respectively, while Table 5 shows the nature of the combinations. The assignment of inner quantum numbers $j$ depends on the fact that the lines $3 d_{1}-2 p_{2}$ and $3 D_{1}-2 p_{2}$ are absent. If we admit that this is an instance of the selection principle for inner numbers, the values adopted are necessary (of course, they can all be changed

${ }^{16}$ Astrophys. J., 34, p. I; I9II.

${ }_{17}$ Jour. de Physique, 4, p. 622, I9r4; and C. R., 171, p. 709; 1920. 
by a constant), and the intensity rules are then found to be fairly well obeyed.

The following pairs are of doubtful significance:

$$
\begin{aligned}
& \lambda \nu \\
& \left.\begin{array}{ll}
8,823 \cdot 3 & \text { II }, 330.6 \\
9,599.3 & \text { I0,4I } 4.6
\end{array}\right\} \Delta \nu=9 \text { I6.o; } \Delta_{3} D=9 \text { I6.23 } \\
& \left.\begin{array}{ll}
\text { I }, 847.7 & 54, \text { I } 2 \text { I } \\
\text { I }, 872.28 & 53,392
\end{array}\right\} \Delta \nu=830 ; \quad \epsilon-\zeta=829.68
\end{aligned}
$$

A convenient point of attack for the discovery of further regularities may be afforded by the narrow pairs at wave lengths I 741.6, I 739.4, and I6I6.7, I6I4.8 A, which exhibit the difference $72.6 \mathrm{~cm}^{-1}$. The pairs 1634.0, 1630.9 and $1574.7,1571.7 \mathrm{~A}$ are also worthy of attention.

\section{ANTIMONY}

The wave lengths of Randall (loc. cit.) extend from I 2 II 8 to $9519 \mathrm{~A}$. In the region 9132 to $553 \mathrm{I} \mathrm{A}$ we have used Walters's data, supplemented where necessary by those of Schippers and of Kretzer, as listed in Kayser's Handbuch. Walters found that some lines were very much stronger near the positive electrode than in any other part of the arc. These lines are indicated by the sign + in the intensity column of Table 7 ; together with a few other lines they have been designated as spark lines in the column of remarks. From 5490 to 2068 A, the wave lengths are those of Schippers, while the data of L. and E. Bloch ${ }^{19}$ were used from 2063 to 1949 A. Beyond that point we have adjusted the wave lengths of Takamine and Nitta, ${ }^{20}$ McLennan, Young, and Ireton, ${ }^{21}$ and $\mathrm{L}$. and $\mathrm{E}$. Bloch. ${ }^{22}$ Table 6 gives the terms of the antimony spectrum, while Table 7 contains wave lengths and classifications. The Zeeman effect in antimony and bismuth was studied by Purvis ${ }^{23}$ and by Van der Harst, ${ }^{24}$ but the results have not been of any aid in classification.

It may be noted that the assumption of an energy level $E$ at $25669.4 \mathrm{I} \mathrm{cm} \mathrm{cm}^{-1}$ gives the following lines:

$$
\begin{aligned}
3 d_{2}-E & =45, \mathrm{I} 84, \\
E-\kappa & =\mathrm{I0}, 047.64 \text { while } \mathrm{I} 0,047.02 \text { is observed. } \\
E-\nu_{2} & =\mathrm{II}, 5 \mathrm{I} 3.3 \mathrm{I} \text { while I I } 5 \mathrm{I} 3.76 \text { is observed. }
\end{aligned}
$$

Since these classifications are uncertain they are not included in Table 7.

\footnotetext{
18 B. S. Sci. Papers, 17, p. I6I; I92x.

19 Jour. de Physique, 4, p. 622; I914.

${ }^{20}$ Kyoto Coll. of Sci. Memoirs, 2, p. II7; I9r7.

${ }^{21}$ Proc. Roy. Soc. 98, p. 95; 1920.

22 C. R., 171, p. 709; r920.

${ }^{23}$ Proc. Cambridge Phil. Soc., 14, p. 216 ; 1907.

${ }^{24}$ Amsterdam Proceedings, 22, p. 300; I920.
} 
TABLE 3.-Term Magnitude in As

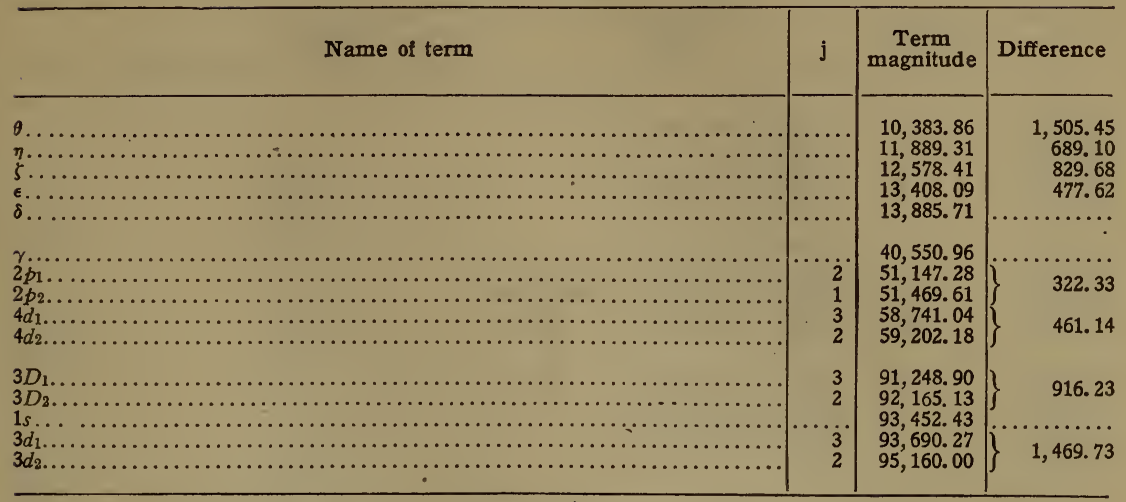

TABLE 4.-Arc Spectrum of Arsenic

\begin{tabular}{|c|c|c|c|c|}
\hline$\lambda$ & Intensity & $\nu$ & $\underset{\text { tion }}{\text { Classifica- }}$ & Remarks \\
\hline $\begin{array}{c}\lambda \text { vac } \\
1,831.1 \ldots \ldots . \\
1,844.3 \ldots \ldots . \\
1,847.7 \ldots \ldots \\
1,850.6 \ldots \ldots \\
1,854.4 \ldots \ldots\end{array}$ & $\begin{array}{l}1 \\
3 \\
2 \\
2 \\
2\end{array}$ & $\begin{array}{l}54,612 \\
54,221 \\
54,121 \\
54,037 \\
53,926\end{array}$ & $\mid \begin{array}{c}3 d_{2}-\gamma \ldots \ldots \\
\cdots \ldots \ldots \ldots \ldots \\
\cdots \ldots \ldots \ldots \ldots \ldots \\
\cdots \ldots \ldots \ldots \ldots \ldots \\
\cdots \ldots \ldots \ldots\end{array}$ & \\
\hline $\begin{array}{c}\lambda \text { I. A. } \\
1,859.90 \ldots \ldots . \\
1,871.07 \ldots \ldots . \\
1,872.33 \ldots \ldots . \\
1,881.08 \ldots \ldots \\
1,889.91 \ldots \ldots .\end{array}$ & $\begin{array}{r}1 \\
1 \\
1 \\
1 \\
4 \mathrm{R}\end{array}$ & $\begin{array}{l}53,748 \\
53,427.4 \\
53,391.4 \\
53,143.2 \\
52,894.9\end{array}$ & $\begin{array}{l}\ldots \\
3 d_{1}-\gamma \ldots \\
1 s-\gamma \ldots \ldots\end{array}$ & Extrapolated. \\
\hline $\begin{array}{l}1,912.27 \ldots . \\
1,916.48 \ldots . \\
1,936.94 \ldots . \\
1,958.31 \ldots . \\
1,971.97 \ldots .\end{array}$ & $\begin{array}{r}1 \\
1 \\
5 R \\
2 \\
4 R\end{array}$ & $\begin{array}{l}52,276.4 \\
52,161.6 \\
51,610.8 \\
51,021.7 \\
50,694.0\end{array}$ & \begin{tabular}{l}
$3 D_{2}-\gamma \ldots$ \\
$3 D_{1}-\gamma \ldots \ldots$ \\
\hdashline$\ldots$
\end{tabular} & \\
\hline $\begin{array}{l}1,990.21 \ldots . \\
1,994.74 \ldots \ldots \\
2,003.35 \ldots . \\
2,009.18 \ldots . \\
2,010.10 \ldots \ldots\end{array}$ & 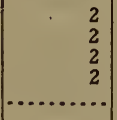 & $\begin{array}{l}50,229.6 \\
50,115.5 \\
49,900.2 \\
49,755.4 \\
49,732.7\end{array}$ & $\begin{array}{l}\ldots \ldots \\
\cdots \ldots \\
\ldots \ldots \\
\ldots \ldots \\
\ldots \ldots \\
\cdots \ldots\end{array}$ & $\begin{array}{l}\text { Diffuse. } \\
\text { Do. } \\
\text { Do. } \\
\text { Kayser and Runge's } \lambda \text {, adjusted }\end{array}$ \\
\hline $\begin{array}{l}2,013.11 \ldots \ldots \\
2,047.75 \ldots \ldots . \\
2,065.43 \ldots \ldots \\
2,067.29 \ldots \ldots \\
2,068.43 \ldots \ldots\end{array}$ & \begin{tabular}{l|}
2 \\
2 \\
2 \\
1 \\
1
\end{tabular} & $\begin{array}{l}49,658.4 \\
48,818.4 \\
48,400.6 \\
48,357.1 \\
48,330.4\end{array}$ & $\begin{array}{l}4 d_{2}-\theta \\
4 d_{1}-\theta \\
\cdots\end{array}$ & Diffuse. \\
\hline $\begin{array}{l}2,069.87 \ldots \ldots \\
2,079.41 \ldots \ldots . \\
2,085.27 \ldots \ldots . \\
2,089.04 \ldots \ldots \\
2,089.73 \ldots \ldots\end{array}$ & $\left|\begin{array}{r}2 \\
1 \\
2 \\
1\end{array}\right|$ & $\begin{array}{l}48,296.9 \\
48,075.1 \\
47,940.0 \\
47,853.5 \\
47,837.7\end{array}$ & $\mid \begin{array}{l}\cdots \\
\cdots \\
\cdots\end{array}$ & $\begin{array}{l}\text { Coincident with a line of Cu. } \\
\text { Kayser and Runge's } \lambda \text {, adjusted. } \\
\text { Diffuse. }\end{array}$ \\
\hline $\begin{array}{l}2,095.10 \ldots \ldots \\
2,109.80 \ldots \ldots \\
2,112.93 \ldots \ldots \\
2,133.70 \ldots \ldots \\
2,144.15 \ldots \ldots\end{array}$ & \begin{tabular}{l|}
2 \\
1 \\
3 \\
2 \\
4
\end{tabular} & $\begin{array}{l}47,715.2 \\
47,382.8 \\
47,312.6 \\
46,852.0 \\
46,623.8\end{array}$ & $\mid \begin{array}{l}\ldots \\
4 d_{2}-\eta \\
4 d_{1}-\eta \ldots \ldots \\
4 d_{2}-\zeta \ldots \ldots\end{array}$ & \\
\hline $\begin{array}{l}2,165.57 \ldots \ldots \\
2,176.30 \ldots \ldots \\
2,183.00 \ldots \ldots \\
2,205.21 \ldots \ldots \\
2,206.01 \ldots \ldots\end{array}$ & \begin{tabular}{l|}
4 \\
1 \\
1 \\
2 \\
2
\end{tabular} & $\begin{array}{l}46,162.6 \\
45,935.1 \\
45,794.0 \\
45,333.0 \\
45,316.5\end{array}$ & $\left|\begin{array}{c}4 d_{1}-\zeta \ldots . . \\
\hdashline 4 d_{2}-\epsilon \ldots \ldots \\
4 d_{1}-\epsilon \ldots . . \\
4 d_{2}-\delta \ldots . .\end{array}\right|$ & \\
\hline $\begin{array}{l}2,228.70 \ldots \ldots \\
2,266.72 \ldots \ldots \\
2,271.39 \ldots \ldots \\
2,288.12 \ldots \ldots \\
2,349.84 \ldots \ldots\end{array}$ & $\begin{array}{r}2 \\
4 \\
4 \\
10 \mathrm{R} \\
10 \mathrm{R}\end{array}$ & $\begin{array}{l}44,855.3 \\
44,103.0 \\
44,012.4 \\
43,690.5 \\
42,543.0\end{array}$ & $\left|\begin{array}{c}4 d_{1}-\delta \ldots . . . \\
3 d_{2}-2 p_{1} \ldots \\
3 d_{2}-2 p_{2} \ldots \\
3 d_{1}-2 p_{1} \ldots\end{array}\right|$ & $\begin{array}{l}\text { Raie ultime. } \\
\text { Do. }\end{array}$ \\
\hline
\end{tabular}


TABLE 4.-Are Spectrum of Arsenic-Continued

\begin{tabular}{|c|c|c|c|c|}
\hline$\lambda$ & Intensity & $\nu$ & $\begin{array}{c}\text { Classifica- } \\
\text { tion }\end{array}$ & Remarks \\
\hline $\begin{array}{r}\lambda \text { I. A. } \\
2,363.04 \ldots \\
2,369.67 \ldots \\
2,370.77 \ldots \\
2,38.20 \ldots \\
2,437.22 \ldots \\
.\end{array}$ & $\begin{array}{r}2 \\
4 \mathrm{R} \\
4 \mathrm{R} \\
4 \mathrm{R} \\
1\end{array}$ & $\begin{array}{l}42,305.4 \\
42,187.1 \\
42,167.4 \\
41,982.7 \\
41,018.0\end{array}$ & 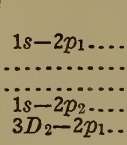 & - \\
\hline $\begin{array}{l}2,456.53 \ldots . . \\
2,492.89 \ldots . \\
2,744.99 \ldots . \\
2,780.20 \ldots \\
2,860.43 \ldots .\end{array}$ & $\begin{array}{l}4 \mathrm{R} \\
1 \\
6 \mathrm{R} \\
8 \mathrm{R} \\
6 \mathrm{R}\end{array}$ & $\begin{array}{l}40,695.6 \\
40,102.0 \\
36,419.2 \\
35,958.0 \\
34,949.5\end{array}$ & $\begin{array}{l}3 D_{2}-2 p_{2} . . \\
3 D_{1}-2 p_{1} \ldots \\
3 d_{2}-4 d_{1} \ldots \\
3 d_{2}-4 d_{2} \ldots \\
3 d_{1}-4 d_{1} \ldots\end{array}$ & $\begin{array}{c}\text { Raie ultime. } \\
\text { Do. } \\
\text { Do. }\end{array}$ \\
\hline $\begin{array}{l}2,898.72 \ldots \ldots \\
2,990.99 \ldots \ldots \\
3,032.84 \ldots \\
3,075.32 \ldots \\
3,119.57 \ldots\end{array}$ & $\begin{array}{r}4 \mathrm{R} \\
2 \\
4 \\
2 \\
4\end{array}$ & $\begin{array}{l}34,487.9 \\
33,424.0 \\
32,962.8 \\
32,507.6 \\
32,046.5\end{array}$ & $\begin{array}{l}3 d_{1}-4 d_{2} \ldots \\
3 D_{2}-4 d_{1} \ldots \\
3 D_{2}-4 d_{2} \ldots \\
3 D_{1}-4 d_{1} \ldots \\
3 D_{1}-4 d_{2} \ldots\end{array}$ & Do. \\
\hline
\end{tabular}

TABLE 5.-Combinations Occurring in the As Spectrum

[A cross indicates that the line is present. Raies ultimes are distinguished by stars]

\begin{tabular}{|c|c|c|c|c|c|c|c|c|c|c|}
\hline & $4 d_{2}$ & $4 d_{1}$ & $2 p_{2}$ & $2 p_{1}$ & $\gamma$ & $\delta$ & $\epsilon$ & $\zeta$ & $\eta$ & $\theta$ \\
\hline \multirow{3}{*}{ 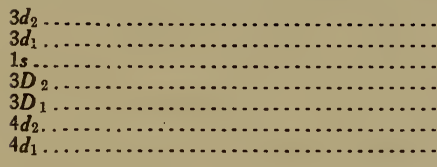 } & $\underset{\times}{X^{*}}$ & $\begin{array}{l}X^{*} \\
x^{*}\end{array}$ & \multirow{3}{*}{$\begin{array}{c}X^{*} \\
\cdots \\
\times \\
\times \\
\cdots \cdots\end{array}$} & \multirow{3}{*}{$\begin{array}{l}\stackrel{x}{\times} \\
\stackrel{x}{x} \\
\stackrel{x}{x} \\
\stackrel{x}{x}\end{array}$} & $\stackrel{x}{x}$ & & & & & \\
\hline & $\begin{array}{l}x \\
x\end{array}$ & $\stackrel{x}{x}$ & & & $\stackrel{x}{x}$ & & & & & $\ldots$ \\
\hline & & & & & & $\stackrel{x}{x}$ & $\stackrel{x}{x}$ & $\stackrel{x}{x}$ & $\stackrel{x}{x}$ & $\stackrel{x}{x}$ \\
\hline
\end{tabular}

TABLE 6.-Term Magnitudes in Antimony

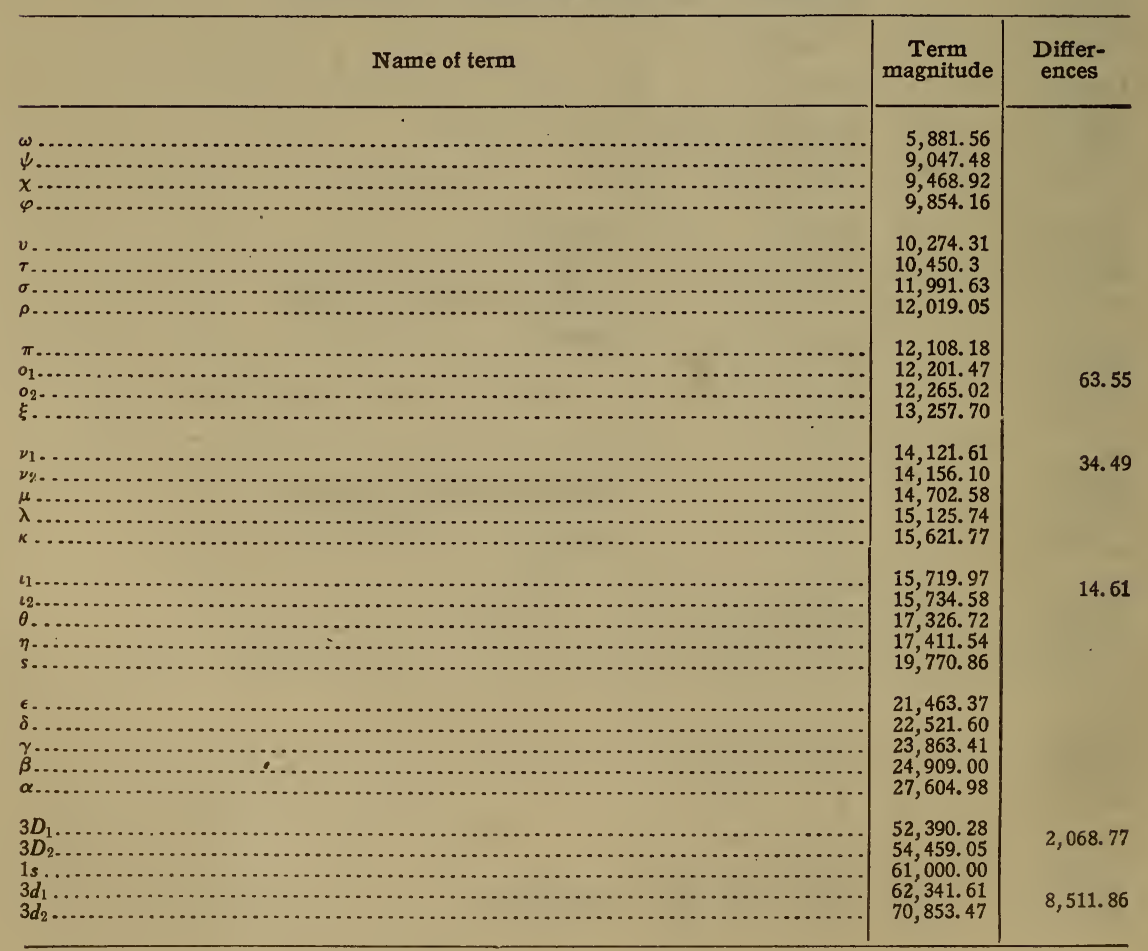


TABLE 7.-Arc Spectrum of Antimony

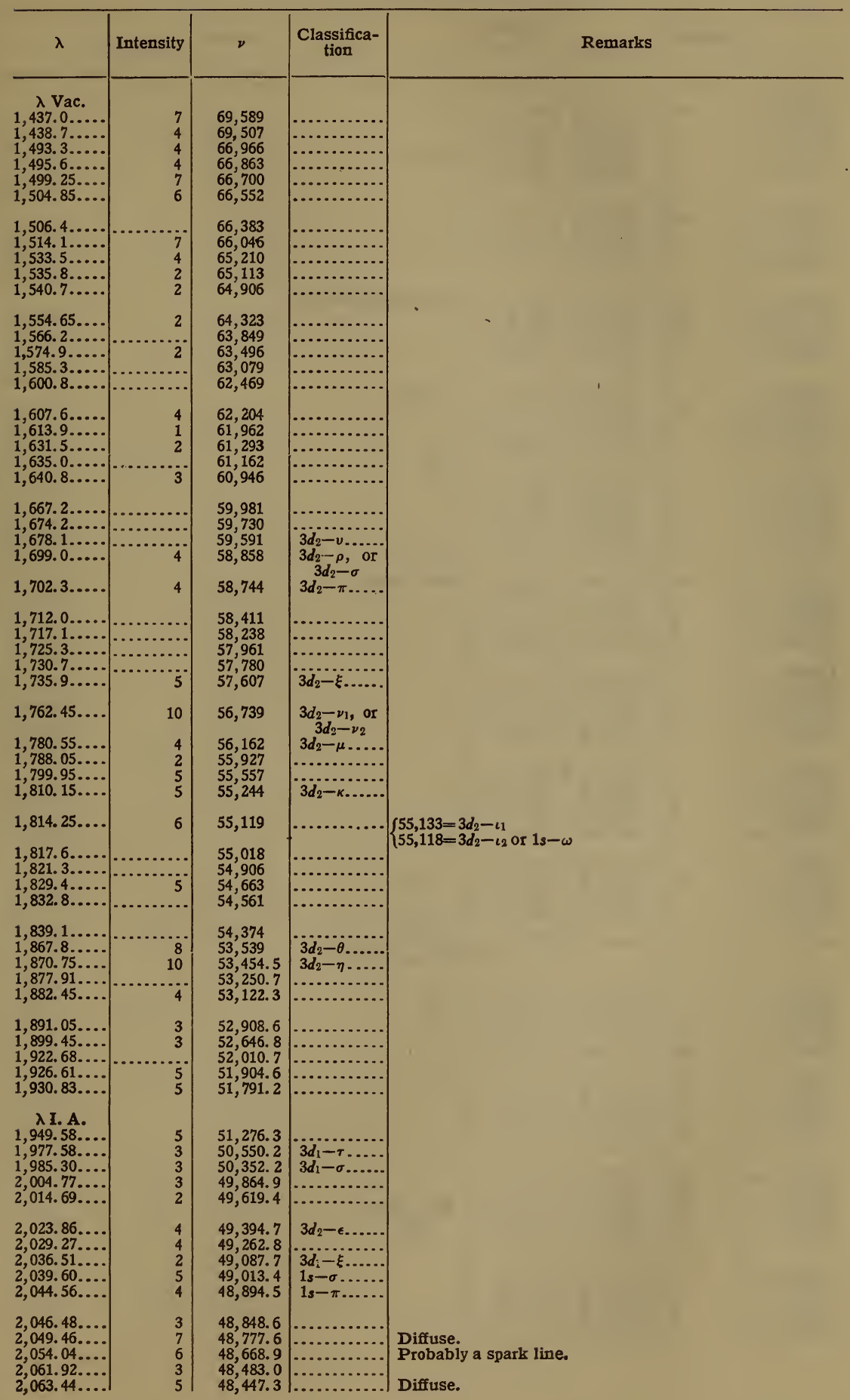


TABLE 7.-Arc Spectrum of Antimony-Continued

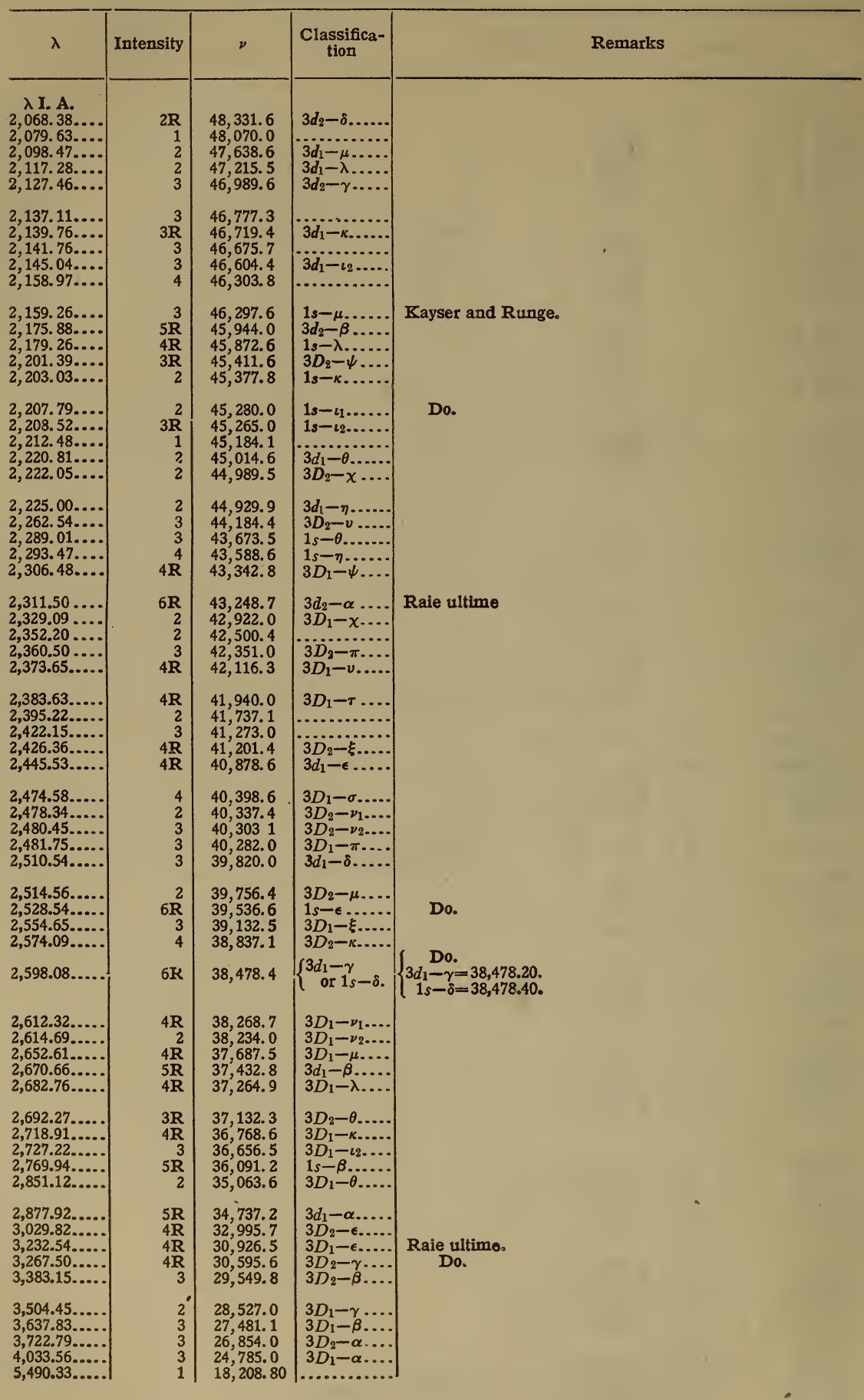


TABLE 7.-Arc Spectrum of Antimony-Continued

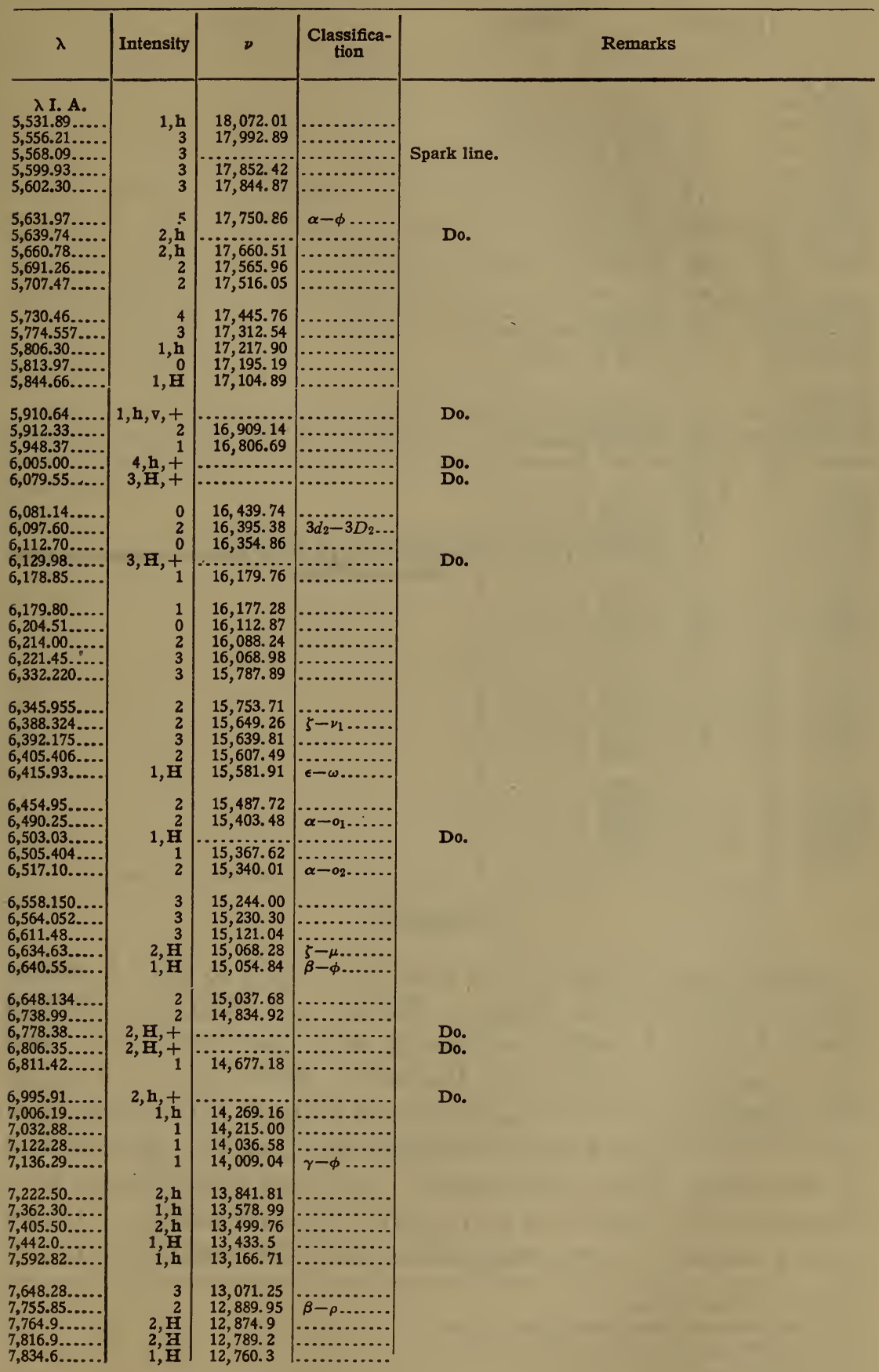


TABLE 7.-Arc Spectrum of Antimony-Continued

\begin{tabular}{|c|c|c|c|c|}
\hline$\lambda$ & Intensity & $\nu$ & $\begin{array}{c}\text { Classifica- } \\
\text { tion }\end{array}$ & Remarks \\
\hline $\begin{array}{c}\lambda \text { I. A. } \\
7,837.25 \ldots \ldots . \\
7,844.44 \ldots \ldots \\
7,867.17 \ldots \ldots \\
7,906.73 \ldots . \\
7,924.65 \ldots . .\end{array}$ & $\begin{array}{l}2 \\
4 \\
2 \\
2 \\
6\end{array}$ & $\begin{array}{l}12,756.08 \\
12,744.37 \\
12,707.56 \\
12,643.98 \\
12,615.38\end{array}$ & {$\left[\begin{array}{ll}\beta \\
\beta-o_{1} . \\
\beta-o_{2} .\end{array}\right]$} & \multirow{8}{*}{$\begin{array}{l}\text { From } 9519 \text { to } 12118 \text { A the intensity numbers are galva- } \\
\text { nometer deflections. }\end{array}$} \\
\hline $\begin{array}{l}7,933.38 \ldots . . \\
7,969.47 \ldots . . \\
8,062.1 \ldots \ldots \\
8,241.74 \ldots . . \\
8,257.56 \ldots .\end{array}$ & 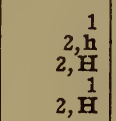 & $\begin{array}{l}12,601.50 \\
12,544.44 \\
12,400.3 \\
12,130.03 \\
12,106.78\end{array}$ & & \\
\hline $\begin{array}{l}8,289.0 \ldots . . . \\
8,314.21 \ldots . . \\
8,411.65 \ldots . . \\
8,572.59 \ldots . \\
8,619.60 \ldots .\end{array}$ & \begin{tabular}{r|}
$2, \mathrm{H}$ \\
1 \\
2 \\
2 \\
2
\end{tabular} & $\begin{array}{l}12,060.8 \\
12,024.30 \\
11,885.01 \\
11,661.89 \\
11,598.29\end{array}$ & $\mid \begin{array}{c}\ldots \\
\alpha-t_{1} \ldots \ldots \\
\gamma-o_{1} \ldots \ldots \\
\gamma-o_{2} \ldots \ldots\end{array}$ & \\
\hline $\begin{array}{l}8,682.88 \ldots . . \\
8,700.20 \ldots . . \\
8,719.79 \ldots . . \\
8,735.0 \ldots . . \\
8,789.2 \ldots . . .\end{array}$ & $\begin{array}{r}1 \\
1 \\
1 \\
1, \mathrm{H} \\
1, \mathrm{H}\end{array}$ & $\begin{array}{l}11,513.76 \\
11,490.83 \\
11,465.02 \\
11,445.0 \\
11,374.4\end{array}$ & \begin{tabular}{c}
$\ldots \ldots$ \\
$0-\omega$ \\
\hdashline$-\omega$
\end{tabular} & \\
\hline $\begin{array}{l}8,860.3 \ldots \ldots . \\
8,903.1 \ldots \ldots . \\
9,019.5 \ldots \ldots \\
9,132.30 \ldots . . \\
9,519.9 . \ldots .\end{array}$ & $\begin{array}{r}1, \mathbf{H} \\
1, \mathbf{H} \\
1, \mathbf{H} \\
1 \\
20\end{array}$ & $\begin{array}{l}11,283.2 \\
11,228.9 \\
11,084.0 \\
10,947.15 \\
10,501.5\end{array}$ & & \\
\hline $\begin{array}{l}9,950.5 \ldots \ldots \\
10,079.9 \ldots . . \\
10,262.9 \ldots . \\
10,587.2 \ldots . \\
10,678.0 \ldots .\end{array}$ & $\begin{array}{r}15 \\
35 \\
40 \\
50 \\
130\end{array}$ & $\begin{array}{r}10,047.2 \\
9,918.0 \\
9,741.2 \\
9,442.8 \\
9,362.6\end{array}$ & $\begin{array}{l}\zeta-\phi \ldots \\
\gamma-\nu_{1} . . \\
\epsilon-\rho \ldots\end{array}$ & \\
\hline $\begin{array}{l}10,742.9 \ldots . . \\
10,840.6 \ldots \\
10,880.3 \ldots . \\
11,013.4 \ldots \\
11,082.7 \ldots .\end{array}$ & $\begin{array}{l}50 \\
50 \\
30 \\
20 \\
15\end{array}$ & $\begin{array}{l}9,305.9 \\
9,222.1 \\
9,188.4 \\
9,077.3 \\
9,020.6\end{array}$ & $\begin{array}{c}\dddot{\beta}-{ }_{1} \ldots \\
\cdots \ldots \ldots\end{array}$ & \\
\hline $\begin{array}{l}11,109.7 \ldots . . \\
11,190.3 \ldots . . \\
11,268.5 \ldots . \\
11,864.3 \ldots . \\
12,118.9 \ldots .\end{array}$ & $\begin{array}{l}15 \\
10 \\
45 \\
40 \\
15\end{array}$ & $\begin{array}{l}8,998.7 \\
8,933.9 \\
8,871.9 \\
8,426.3 \\
8,249.3\end{array}$ & & \\
\hline
\end{tabular}

6. BISMUTH

Randall's wave lengths were used from 22554 to 9657 A, where Walters' observations began. Kayser and Runge's numbers extend to 206I A, while the lines at 2073, 2069, 2049, 202I, and $2020 \mathrm{~A}$ are due to Eder and Valenta. ${ }^{25}$ From 1990 to $1902 \mathrm{~A}$ the numbers are those of Takamine and Nitta. ${ }^{26}$ The region from 1900 to $1400 \mathrm{~A}$ has been investigated by $\mathrm{L}$. and $\mathrm{E}$. Bloch ${ }^{27}$ and by McLennan, Young, and Ireton. ${ }^{28}$ Since no classifications were obtained in this region we do not give the wave lengths. Tables 8 and 9 contain the term magnitudes, the wave lengths and classi-

${ }^{25}$ Atlas Typischer Ś Sectren, I9rr.

${ }^{26}$ Kyoto College of Science Memoirs, 2, p. xr7; rgr7.

${ }^{27}$ C. R., 170, p. 320 , and 171, p. 709; I920.

28 Proc. Roy. Soc., 98, p. 95; 1920. 
fications. The following pairs are characterized by the difference 348.59:

\begin{tabular}{cc}
\multicolumn{1}{c}{$\lambda$} & \multicolumn{1}{c}{$\nu$} \\
$9,657.20$ & I0,352.I4 \\
$9,342.60$ & I0, 700.73 \\
8,76 I. 54 & II, 4 I0.40 \\
8,5 OI.8 & II, $75^{8} .99$
\end{tabular}

It must be mentioned that we can do away with the orbits $3 d_{1} \mathrm{~A}, \mathrm{I} s$, and $\rho$, provided we introduce three others at 51031.43 4610.46 , and 5 I03.22. However, this will leave the line $1 s-\zeta$ unclassified, and will destroy the symmetry of arrangement of the $3 d$ and ${ }_{3} D$ groups. The correct allocation can not be decided without new data.

NOTE ADDED MARCH 20, I924.-Unfortunately, the wave lengths of Offermann, given in the seventh volume of Kayser and Konen's Handbuch, were not available at the time this paper was written. So far as can be seen, no changes are made necessary by the new data.

TABLE 8.-Term Magnitudes in Bismuth

\begin{tabular}{|c|c|c|}
\hline Name of term & $\begin{array}{c}\text { Term } \\
\text { magnitude }\end{array}$ & Differences \\
\hline 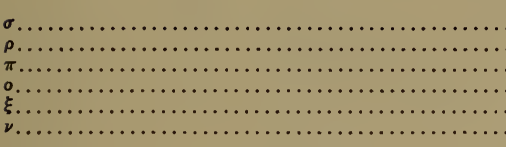 & $\begin{array}{l}4,596.41 \\
5,015.92 \\
5,793.98 \\
6,299.53 \\
6,781.38 \\
8,991.08\end{array}$ & 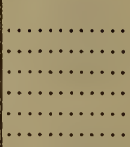 \\
\hline 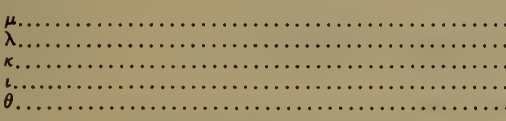 & $\begin{array}{l}11,711.13 \\
11,850.00 \\
13,408.29 \\
14,379.67 \\
15,496.12\end{array}$ & 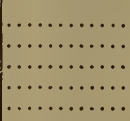 \\
\hline 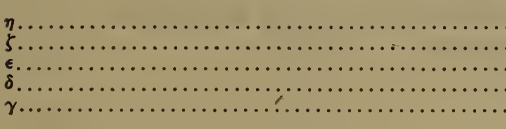 & $\begin{array}{l}16,953.70 \\
18,004.03 \\
18,052.13 \\
18,956.53 \\
21,742.76\end{array}$ & 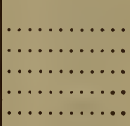 \\
\hline 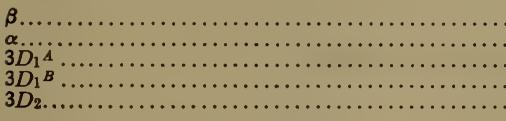 & $\begin{array}{l}29,703.81 \\
30,280.38 \\
41,207.49 \\
41,209.34 \\
47,431.76\end{array}$ & $\begin{array}{r}\cdots, \ldots \ldots \\
6,222.42\end{array}$ \\
\hline 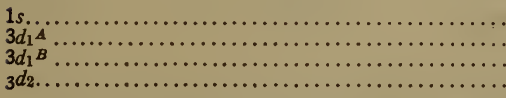 & $\begin{array}{l}50,944.00 \\
51,435.95 \\
51,450.00 \\
62,868.26\end{array}$ & $\begin{array}{r}14.05 \\
11,418.26\end{array}$ \\
\hline
\end{tabular}


TABLE 9.-Arc Spectrum of Bismuth

\begin{tabular}{|c|c|c|c|c|}
\hline$\lambda$ & Intensity & $\nu$ & $\begin{array}{c}\text { Classifica- } \\
\text { tion }\end{array}$ & Remarks \\
\hline $\begin{array}{c}\lambda \text { vac. } \\
1,902.6 \ldots \ldots . \\
1,910.2 \ldots \ldots . \\
1,953.9 \ldots \ldots . \\
1,959.7 \ldots \ldots . \\
1,973.3 \ldots \ldots . \\
1,988.9 \ldots \ldots . \\
1,990.2 \ldots \ldots .\end{array}$ & $\begin{array}{r}10 \\
2 \\
5 \\
2 \\
2 \\
4 \\
1\end{array}$ & $\begin{array}{l}52,561 \\
52,352 \\
51,181 \\
51,030 \\
50,678 \\
50,280 \\
50,248\end{array}$ & 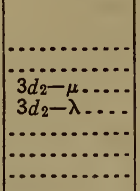 & L. and E. Bloch give $1,973.09$ and $1,959.57 \mathrm{~A}, \Delta \nu=349.7$. \\
\hline $\begin{array}{c}\lambda \text { I. A. } \\
2,020.5 \ldots \ldots . \\
2,020.99 \ldots \ldots \\
2,049.59 \ldots \ldots \\
2,061.71 \ldots . . \\
2,068.99 \ldots \ldots\end{array}$ & $\begin{array}{r}1 \\
1 \\
2 \\
10 \mathrm{R} \\
2\end{array}$ & $\begin{array}{l}49,476 \\
49,464.7 \\
48,774.5 \\
48,487.9 \\
48,317.4\end{array}$ & \begin{tabular}{c}
$3 d_{2}-\kappa$ \\
\hdashline $3 d_{2}-\iota$ \\
$\ldots \ldots$
\end{tabular} & \\
\hline $\begin{array}{l}2,073.2 \ldots \ldots . \\
2,110.29 \ldots . . \\
2,133.66 \ldots . . \\
2,134.32 \ldots . . \\
2,152.91 \ldots . .\end{array}$ & $\begin{array}{r}\mathbf{3} \\
10 \mathrm{R} \\
8 \mathrm{R} \\
10 \mathrm{R} \\
8 \mathrm{R}\end{array}$ & $\begin{array}{l}48,218 \\
47,371.9 \\
46,853.0 \\
46,838.5 \\
46,434.0\end{array}$ & 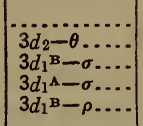 & $*$ \\
\hline $\begin{array}{l}2,153.53 \ldots . . \\
2,156.96 \ldots . . \\
2,164.09 \ldots . \\
2,176.63 \ldots . \\
2,177.33 \ldots .\end{array}$ & $\begin{array}{r}4 R \\
10 R \\
4 R \\
6 R\end{array}$ & $\begin{array}{l}46,420.4 \\
46,346.8 \\
46,194.2 \\
45,928.2 \\
45,913.4\end{array}$ & 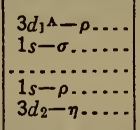 & \\
\hline $\begin{array}{l}2,189.63 \ldots \ldots . \\
2,203.1 \ldots \ldots . \\
2,214.14 \ldots \ldots \\
2,224.20 \ldots . . \\
2,228.24 \ldots . .\end{array}$ & $\begin{array}{r}8 \mathrm{R} \\
6 \mathrm{U} \\
4 \\
2 \\
8 \mathrm{R}\end{array}$ & $\begin{array}{l}45,655.4 \\
45,375.70 \\
45,150.2 \\
44,946.0 \\
44,864.6\end{array}$ & \begin{tabular}{c}
$3 d_{1}{ }^{B}-\pi$ \\
\hdashline $3 d_{1}^{B}-0$. \\
\hdashline $3 d_{2}-\zeta$
\end{tabular} & \\
\hline $\begin{array}{l}2,230.63 \ldots \ldots \\
2,276.57 \ldots \ldots \\
2,281.32 \ldots . . \\
2,328.19 \ldots . \\
2,333.79 \ldots \ldots\end{array}$ & $\begin{array}{r}10 \mathrm{R} \\
8 \mathrm{R} \\
2 \mathrm{U} \\
2 \mathrm{r} \\
2\end{array}$ & $\begin{array}{l}44,816.3 \\
43,912.1 \\
43,820.5 \\
42,938.5 \\
42,835.5\end{array}$ & 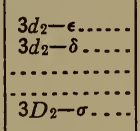 & \\
\hline $\begin{array}{l}2,354.49 \ldots \ldots . \\
2,400.90 \ldots . . \\
2,430.43 \ldots . . \\
2,433.4 \ldots \ldots \\
2.448 .07 \ldots \ldots\end{array}$ & $\begin{array}{r}2 \mathrm{U} \\
8 \mathrm{R} \\
2 \mathrm{U} \\
4 \mathrm{U} \\
4\end{array}$ & $\begin{array}{l}42,459.0 \\
41,638.4 \\
41,132.5 \\
41,082.0 \\
40,836.2\end{array}$ & 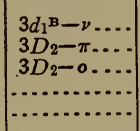 & $\begin{array}{l}\text { Visible at } 10.8 \text { volts. May be Sn. } \\
\text { Visible at } 7.8 \text { volts. }\end{array}$ \\
\hline $\begin{array}{l}2,489.4 \ldots \ldots . \\
2,515.63 \ldots . . \\
2,524.49 \ldots . \\
2,532.56 \ldots . \\
2,582.08 \ldots . .\end{array}$ & $\begin{array}{r}6 \mathrm{U} \\
6 \mathrm{R} \\
2 \\
4 \mathrm{U} \\
2\end{array}$ & $\begin{array}{l}40,158.0 \\
39,739.4 \\
39,600.0 \\
39,473.9 \\
38,717.0\end{array}$ & $\begin{array}{c}3 d_{1^{\mathrm{B}}-\mu} \\
3 d_{1}{ }^{\mathrm{B}}-\lambda \\
\ldots \ldots \ldots \\
\cdots\end{array}$ & $\begin{array}{l}\text { Not on our plates. } \\
\text { On our plates } 2,515 \text { and } 2,524 \text { are equally intense. } \\
\text { Not on our plates. } \\
\text { Do. }\end{array}$ \\
\hline $\begin{array}{l}2,594.05 \ldots \ldots . \\
2,600.64 \ldots . . \\
2,627.89 \ldots . . \\
2,696.59 \ldots . . \\
2,696.74 \ldots \ldots\end{array}$ & $\begin{array}{r}1 \\
1 \\
8 R \\
5 \\
6 R\end{array}$ & $\begin{array}{l}38,538.2 \\
38,440.6 \\
38,042.0 \\
37,072.9 \\
37,070.8\end{array}$ & $\begin{array}{l}3 D_{2}-\nu \ldots . \\
3 d_{1}^{\mathrm{B}}-\kappa \\
3 d_{1}\end{array}$ & Diffuse in under-water spark. \\
\hline $\begin{array}{l}2,730.35 \ldots \ldots \\
2,730.51 \ldots \ldots \\
2,780.47 \ldots \ldots \\
2,798.65 \ldots \\
2,809.63 \ldots .\end{array}$ & $\begin{array}{r}3 \\
6 \mathbf{R} \\
8 \mathbf{R} \\
4 \\
8 \mathbf{R}\end{array}$ & $\begin{array}{l}36,614.4 \\
36,612.3 \\
35,954.5 \\
35,720.1 \\
35,581.3\end{array}$ & $\begin{array}{l}3 D_{1}^{B}-\sigma \ldots \\
3 D_{1}{ }^{\mathrm{A}}-\sigma \ldots \\
3 d_{1} \mathrm{~B}-\theta \ldots \\
3 D_{2}-\mu \ldots \\
3 D_{2}-\lambda \ldots\end{array}$ & Raie ultime. \\
\hline $\begin{array}{l}2,863.75 \ldots \ldots \\
2,883.77 \ldots \ldots \\
2,897.97 \ldots \ldots \\
2,938.30 \ldots \\
2,989.03 \ldots\end{array}$ & $\begin{array}{r}4 \\
1 \mathrm{u} \\
10 \mathrm{R} \\
10 \mathrm{R} \\
8 \mathrm{R}\end{array}$ & $\begin{array}{l}34,909.0 \\
34,666.7 \\
34,496.8 \\
34,023.4 \\
33,445.9\end{array}$ & $\begin{array}{l}3 D_{1} \mathrm{~A}, \mathrm{~B}-0 . \\
3 d_{1}^{\mathrm{B}}-\eta_{\ldots} \\
3 D_{2}-K_{\ldots} \\
3 d_{1}^{\mathrm{B}}-\zeta \ldots .\end{array}$ & $\begin{array}{l}\text { Do. } \\
\text { Do. } \\
\text { Do. }\end{array}$ \\
\hline $\begin{array}{l}2,993.34 \ldots . . \\
3,024.63 \ldots . \\
3,034.87 \ldots \ldots \\
3,067.69 \ldots \ldots \\
3,076.61 \ldots \ldots \\
3,397.17 \ldots \ldots\end{array}$ & $\begin{array}{r}8 \mathrm{R} \\
8 \mathrm{R} \\
4 \mathrm{r} \\
10 \mathrm{R} \\
2 \\
4 \mathrm{R}\end{array}$ & $\begin{array}{r}33,397.7 \\
33,052.3 \\
32,940.8 \\
32,588.4 \\
32,493.9 \\
29,427.8\end{array}$ & $\begin{array}{l}3 d_{1}{ }^{B}-\epsilon . . \\
3 D_{2}-\iota . . . \\
1 s-\zeta ? . . \\
3 d_{2}-\alpha . . \\
3 d_{1}{ }^{B}-\delta . . \\
3 D_{2}-\zeta \ldots\end{array}$ & $\begin{array}{l}\text { May be a 14-volt line. } \\
\text { Raie ultime. } \\
\text { Diffuse toward red in under-water spark. Bloch, Jour. } \\
\text { de Phys. (5) } 3, \text { p. } 309,1922 \text {. }\end{array}$ \\
\hline $\begin{array}{l}3,405.18 \ldots \ldots \\
3,405.25 \ldots \ldots \\
3,510.88 \ldots \\
3,596.11 \ldots \\
3,887.90 \ldots\end{array}$ & $\begin{array}{r}3 \\
4 \mathrm{R} \\
4 \mathrm{R} \\
1\end{array}$ & $\begin{array}{l}29,359.3 \\
29,358.0 \\
28,475.0 \\
27,799.9 \\
25,713.6\end{array}$ & $\begin{array}{l}3 D_{1}^{\mathrm{B}}-\lambda \ldots \\
3 D_{1}^{\mathrm{A}}-\lambda \ldots \\
3 D_{2}-\delta \ldots \\
3 D_{1}^{\mathrm{A}}, \mathrm{B}-\kappa \\
3 D_{1}^{\mathrm{B}}-\theta \ldots\end{array}$ & Diffuse toward red in under-water spark. \\
\hline
\end{tabular}


TABLE 9.-Arc Spectrum of Bismuth-Continued.

\begin{tabular}{|c|c|c|c|c|}
\hline$\lambda$ & Intensity & $\nu$ & $\begin{array}{l}\text { Classifica- } \\
\text { tion. }\end{array}$ & Remarks \\
\hline $\begin{array}{r}\lambda \text { I. A. } \\
3,888.19 \ldots \\
4,121.54 \ldots \\
4,121.86 \ldots \\
4,254.17 \ldots \\
4,272.5 \ldots \\
4,308.18 \ldots \\
4,308.54 \ldots \\
4,492.62 \ldots \\
4,492.99 \ldots \\
4,615.09 \ldots\end{array}$ & $\begin{array}{r}1 \\
6 \\
6 \\
1 \mathrm{u} \\
2 \mathrm{u} \\
4 \\
4 \\
2 \\
2 \\
1\end{array}$ & $\begin{array}{l}25,711.6 \\
24,256.0 \\
24,254.1 \\
23,499.8 \\
23,398.7 \\
23,205.2 \\
23,203.2 \\
22,252.5 \\
22,250.7 \\
21,662.0\end{array}$ & 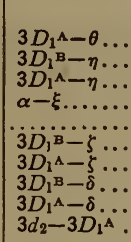 & $\begin{array}{l}\text { Diffuse toward red in under-water spark. } \\
\text { Appears at } 8.5 \text { volts. Not recorded in arc in air. }\end{array}$ \\
\hline $\begin{array}{l}4,615.53 \ldots \\
4,722.54 \ldots \\
4,733.73 \ldots \\
5,298.34 \ldots \\
5,552.35 \ldots\end{array}$ & $\begin{array}{r}10 R \\
4 \mathrm{r} \\
2 \mathrm{r} \\
10, \mathrm{~B}, \mathrm{r}\end{array}$ & $\begin{array}{l}21,659.9 \\
21,169.1 \\
21,119.1 \\
18,868.6 \\
18,004.69\end{array}$ & $\begin{array}{l}3 d_{2}-3 D_{1}^{B} \\
3 d_{1}^{B}-\alpha \cdots \\
\cdots \cdots \cdots \cdots \cdots \\
\cdots \cdots \cdots \cdots \cdots\end{array}$ & $\begin{array}{l}\text { Raie ultime. } \\
\text { May be a flame line, sccording to Schwetz. }\end{array}$ \\
\hline $\begin{array}{l}5,599.41 \ldots \\
5,742.55 \ldots \\
6,134.82 \ldots \\
6,184.99 \ldots \\
6,364.75 \ldots\end{array}$ & $\begin{array}{r}3 \\
6, \mathrm{r} \\
6 \\
2, \mathrm{H} \\
1, \mathrm{~h}\end{array}$ & $\begin{array}{l}17,853.38 \\
17,408.38 \\
16,295.35 \\
16,163.15 \\
15,706.67\end{array}$ & $\begin{array}{l}\beta-\lambda . \\
\dddot{\beta}-\kappa_{-} \\
\cdots \cdots \\
\cdots \cdots\end{array}$ & \\
\hline $\begin{array}{l}6,475.73 \ldots . \\
6,476.24 \ldots \\
6,991.12 \ldots \\
7,036.15 \ldots \\
7,335.01 \ldots\end{array}$ & $\begin{array}{r}3 \\
3 \\
\mathbf{H} \\
2 \\
1\end{array}$ & $\begin{array}{l}15,437.53 \\
15,436.32 \\
14,299.40 \\
14,207.87 \\
13,628.99\end{array}$ & 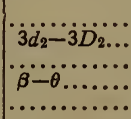 & \\
\hline $\begin{array}{l}7,441.25 \ldots . \\
7,502.33 \ldots \\
7,838.70 \ldots \\
7,840.33 \ldots \\
8,210.83 \ldots\end{array}$ & $\begin{array}{r}1, \mathbf{h} \\
2 \\
3 \\
2 \\
1, \mathbf{h}\end{array}$ & $\begin{array}{l}13,434.40 \\
13,325.03 \\
12,753.25 \\
12,750.60 \\
12,175.25\end{array}$ & \begin{tabular}{c}
$\ldots \ldots$ \\
$\cdots \ldots$. \\
\hdashline$\beta$ \\
$\delta-\eta$ \\
$\delta-\xi$.
\end{tabular} & \\
\hline $\begin{array}{l}8,501.8 \ldots \ldots \\
8,544.54 \ldots . \\
8,579.74 \ldots \\
8,627.9 \ldots \\
8,754.88 \ldots\end{array}$ & $\begin{array}{r}1, \mathrm{H}, \mathrm{b} \\
2 \\
1 \\
1, \mathrm{H}, \mathrm{b} \\
2\end{array}$ & $\begin{array}{l}11,758.51 \\
11,699.70 \\
11,651.69 \\
11,586.65 \\
11,418.61\end{array}$ & 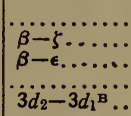 & $\begin{array}{c}5 \mathrm{~A} \text { wide. } \\
\text { Do. }\end{array}$ \\
\hline $\begin{array}{l}8,761.54 \ldots . \\
8,907.81 \ldots \\
9,058.62 \ldots . \\
9,342.60 \ldots \\
9,657.20 \ldots\end{array}$ & $\begin{array}{r}3 \\
2 \\
1 \\
1, \mathbf{h} \\
2\end{array}$ & $\begin{array}{l}11,409.93 \\
11,222.58 \\
11,035.74 \\
10,700.28 \\
10,351.70\end{array}$ & $\begin{array}{c}\xi-\xi \ldots \\
\ldots \ldots \ldots \\
\cdots \ldots \ldots \\
\cdots \ldots\end{array}$ & \\
\hline $\begin{array}{l}9,828.8 \ldots \ldots \\
10,106.1 \ldots \\
10,301.7 \ldots \\
10,540.2 \ldots \\
11,073.2 \ldots\end{array}$ & $\begin{array}{r}120 \mathrm{~mm} \\
20 \\
15 \\
8 \\
15\end{array}$ & $\begin{array}{r}10,171.5 \\
9,892.3 \\
9,704.5 \\
9,484.9 \\
9,028.4\end{array}$ & 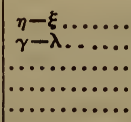 & \\
\hline $\begin{array}{l}11,555.5 \ldots . \\
11,711.1 \ldots \\
11,994.5 \ldots \\
12,166.5 \ldots\end{array}$ & $\begin{array}{r}5 \\
160 \\
13 \\
40\end{array}$ & $\begin{array}{l}8,651.5 \\
8,536.6 \\
8,334.9 \\
8,217.0\end{array}$ & $\begin{array}{c}\alpha \ldots \ldots \ldots \ldots \\
\gamma-\kappa \ldots \ldots \ldots\end{array}$ & \\
\hline $\begin{array}{l}12,296 \ldots \ldots \\
12,690.5 \ldots \\
14,331.5 \ldots \\
22,554.2 \ldots\end{array}$ & $\begin{array}{r}30 \\
25 \\
7\end{array}$ & $\begin{array}{l}8,132.7 \\
7,877.8 \\
6,975.8 \\
4,432.6\end{array}$ & 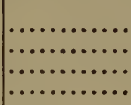 & Lehmann, Ann. d. Phys., 39, p. 53, 1912. \\
\hline
\end{tabular}

${ }^{1}$ From 9828 to $22554 \mathrm{~A}$ the intensity numbers represent galvanometer deflections. They are from 5 to 20 times as large as intensities estimated from photographs of the region around I0000 $\mathrm{A}$, when the latter are expressed on a scale of $\mathrm{I}$ to $\mathrm{IO}$.

\section{HIGHER STAGES IN THE BISMUTH SPECTRA}

Starting from the fact that the difference 203.65 occurs several times in the $\mathrm{I} 4$-volt lines of $\mathrm{Bi}$, it is possible to correlate $\mathrm{I}_{3}$ lines by means of the energy levels given below. These levels are designated by arbitrary letters and the term magnitudes are also arbitrary. It may even occur that the direction of increase of the terms should be reversed. Many spark lines are recorded only 
by one observer and frequently the wave lengths are given only to o.I A. For these reasons no attempt was made to push the classifications too far, and a complete list of wave lengths will not be given.

Terms of the 14-Volt Spectrum of Bismuth

\begin{tabular}{|c|c|c|}
\hline Name & $\nu$ & $\Delta \nu$ \\
\hline $\begin{array}{l}N \ldots \ldots \\
M \ldots \ldots \\
L \ldots \ldots \\
K \ldots \ldots\end{array}$ & $\begin{array}{l}78,636.45 \\
79,750.78 \\
79,796.35 \\
80,000.00\end{array}$ & $\begin{array}{r}1,114.33 \\
45.57 \\
203.65\end{array}$ \\
\hline 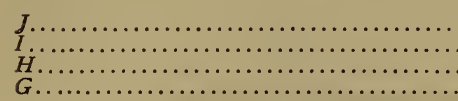 & $\begin{array}{l}96,313.20 \\
99,432.43 \\
105,93.30 \\
108,933.93\end{array}$ & $\begin{array}{l}3,119.23 \\
2,940.63\end{array}$ \\
\hline
\end{tabular}

The correlated lines are as follows:

\begin{tabular}{|c|c|c|c|}
\hline$\lambda$ I. A. & Intensity & $\nu$ & $\begin{array}{l}\text { Classifi- } \\
\text { cation }\end{array}$ \\
\hline $\begin{array}{l}3,299.7 \\
3,431.01 \ldots \ldots \ldots \ldots \ldots \ldots \\
3,455.2 \ldots \ldots \ldots \ldots \ldots \ldots \ldots \\
3,654.4 \ldots \ldots \ldots \ldots \ldots \ldots \ldots \\
3,816.1 \ldots \ldots \ldots \ldots \ldots \ldots \ldots\end{array}$ & $\begin{array}{l}1 \mathrm{u} \\
20 \\
1 \mathrm{u} \\
1 \mathrm{u} \\
4 \mathrm{u}\end{array}$ & $\begin{array}{l}30,297.4 \\
29,137.6 \\
28,934.0 \\
27,356.8 \\
26,197.0\end{array}$ & $\begin{array}{l}G-N \\
G-L \\
G-K \\
H-N \\
H-L\end{array}$ \\
\hline $\begin{array}{l}3,846.0 \ldots \ldots \ldots . . \\
5,079.52 \ldots \ldots \ldots . \\
5,091.22 \ldots \ldots \ldots . \\
5,144.57 \ldots \ldots \ldots .\end{array}$ & $\begin{array}{r}2 u \\
1 \\
1 \\
5\end{array}$ & $\begin{array}{l}25,993.3 \\
19,681.4 \\
19,636.2 \\
19,432.6\end{array}$ & $\begin{array}{l}H-K \\
I-M \\
I-L \\
I-K\end{array}$ \\
\hline $\begin{array}{l}5,655.58 \ldots \ldots \ldots \ldots \ldots \ldots \ldots \\
6,036.00 \ldots \ldots \ldots \ldots \ldots \ldots \ldots \ldots \ldots \ldots \ldots \ldots \ldots \ldots \ldots \ldots \ldots \ldots \ldots \\
6,052.79 \ldots \ldots \ldots \ldots \ldots \ldots \ldots \ldots\end{array}$ & $\begin{array}{r}3 \\
2 \mathrm{u} \\
1 \mathrm{u} \\
3\end{array}$ & $\begin{array}{l}17,676.7 \\
16,562.7 \\
16,516.8 \\
16,313.1\end{array}$ & $\begin{array}{l}J-N \\
J-M \\
J-L \\
J-K\end{array}$ \\
\hline
\end{tabular}

A few other frequency differences may be significant. The very intense lines

$$
\begin{array}{ll}
3,792.8 \mathrm{~A}, & 26,357.92 \mathrm{~cm}^{-1} \\
4,302.09 \mathrm{~A}, & 23,237.99 \mathrm{~cm}^{-1}
\end{array}
$$

appear at $\mathrm{x} 4$ volts, and have the frequency difference $I-J . \quad 3793 \mathrm{~A}$ is quite resistant to self-induction, according to Hemsalech. ${ }^{29}$ There is a strong pair in the vacuum arc spectrum at 1538.5 and I $533.7 \mathrm{~A}$, which has the separation $K-L$.

There are two pairs, each including a strong reversed line, which have the separation 300.12 :

$\begin{array}{cc}\lambda \text { I. A. } & \nu \\ 5,8 \mathrm{I} 8.98(2 \mathrm{u}) & \mathrm{I} 7, \mathrm{I} 80.39 \\ 5,7 \mathrm{I} 9.08(6 \mathrm{R}) & \mathrm{I} 7,480.50 \\ 4,797.67(3 \mathrm{u}) & 20,837.63 \\ 4,729.55(3 \mathrm{R}) & 2 \mathrm{I}, \mathrm{I} 37.77\end{array}$

The difference 300.12 and the cross difference 3657.26 did not lead to any further classifications.

WASHINGTON, January 20, 1924.

${ }^{29}$ Jour. de Phys. (3), 8, p. $562 ; 1899$. 